Volume 10 Number 4, October-December 2016: pp. 605-820.

Copyright (c) 2015-2016 FIAT JUSTISIA. Faculty of Law, Lampung University, Bandarlampung, Lampung, Indonesia. ISSN: $1978-5186$ | e-ISSN: 2477-6238.

Open Access: http://jurnal.fh.unila.ac.id/index.php/fiat

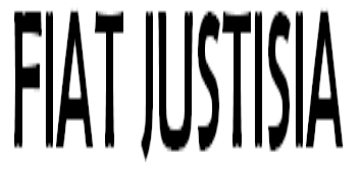

Fiat Justisia is licensed under a Creative Commons Attribution 4.0 International License, which permits unrestricted use, distribution, and reproduction in any medium, provided the original work is properly cited.

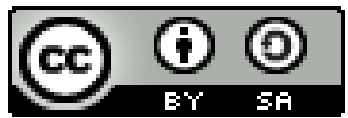

\title{
KESIAPAN UNDANG-UNDANG NOMOR 20 TAHUN 2016 TENTANG MEREK DAN INDIKASI GEOGRAFIS DALAM MENGHADAPI MASYARAKAT EKONOMI ASEAN
}

\section{The Rule of Law of an Alumni Function in the Implementation of Higher Education in the Lampung University}

\author{
Tomy Pasca Rifai \\ Lembaga Bantuan Hukum Sopian Sitepu \& Partners \\ Email: tomypasca1@gmail.com
}

\begin{abstract}
The readiness of legal protection in the Law No. 20 of 2016 on the Trademarks and Geographical Indications in facing the ASEAN Economic Community emphasizes the competitive economic region, namely the expansion of the definition of the trademark, the registration of international trademark based on Madrid Protocol, the simplification of a trademark registration period procedures, the guidance and supervision of geographical indications, the use of electronic or non-electronic media, as well as network documentation system and geographical indications organized by electronic devices and/ or non-electronic which accessible nationally and internationally.
\end{abstract}

Keywords: ASEAN Economic Community, trademarks, geographical indications, national interest

\footnotetext{
Abstrak

Kesiapan perlindungan hukum dalam UU Nomor 20 Tahun 2016 tentang Merek Dagang dan Indikasi Geografis dalam menghadapi Masyarakat Ekonomi ASEAN menekankan wilayah ekonomi yang kompetitif, yaitu perluasan definisi merek dagang, pendaftaran merek dagang internasional berdasarkan Protokol Madrid, penyederhanaan periode prosedur pendaftaran merek, bimbingan dan pengawasan dari indikasi geografis, penggunaan media elektronik atau non-elektronik, serta sistem jaringan dokumentasi dan
} 
indikasi geografis yang diselenggarakan oleh perangkat elektronik dan/atau non-elektronik yang dapat diakses secara nasional dan internasional.

Kata Kunci: Masyarakat Ekonomi ASEAN, Merek Dagang, Indikasi Geografis, Kepentingan Nasional

\section{A. Pendahuluan}

Perkembangan dunia di era millenium ketiga ini ditandai dengan semakin pesatnya loncatan kemajuan bidang ilmu pengetahuan dan teknologi (IPTEK). Perkembangan ini terasa semakin multi dimensi ketika dihadapkan pada tuntutan dan kebutuhan manusia yang beragam. ${ }^{1}$ Kompleksitas ini semakin bertambah manakala dihubungkan dengan pola interaksi bisnis yang terjalin di masyarakat modern. Implikasi ini telah mengubah wajah perdagangan dan perekonomian dunia menjadi bentuk bisnis secara global. Globalisasi ekonomi berarti terintegrasinya ekonomi berbagai negara menjadi satu seolah-olah tanpa dibatasi oleh kedaulatan negara. Salah satu ciri bisnis yang paling dominan pada globalisasi ekonomi adalah sifatnya bergerak cepat, baik dalam transaksi maupun pergerakan arus barang dan modal. Hal ini mempengaruhi pula terhadap berbagai peraturan di bidang bisnis yang dengan cepat pula mengalami perubahan. ${ }^{2}$

Pada tahun 2003, negara-negara anggota ASEAN mengadakan pertemuan di Bali dengan gagasan untuk mewujudkan cita-cita kawasan yang memiliki integritas ekonomi kuat mulai dirancang langkah awal dan diprediksikan akan dimulai pada tahun 2020. Selanjutnya, pada pertemuan di Filipina yang diselenggarakan pada 13 Januari 2007, para negara-negara anggota ASEAN sepakat untuk mempercepat pembentukan Masyarakat Ekonomi ASEAN (dalam istilah bahasa Inggris: ASEAN Economic Community (AEC)), selanjutnya dalam penulisan ini disebut sebagai MEA. Latar belakang pembentukan ini adalah untuk persiapan menghadapi globalisasi ekonomi dan perdagangan melalui ASEAN Free Trade Area (AFTA) serta menghadapi persaingan global terutama dari China dan India. Percepatan keputusan negara ASEAN untuk membentuk MEA yang pada awalnya baru akan dimulai pada tahun 2020 menjadi 2015 menjadi acuan untuk segera meningkatkan pertumbuhan ekonomi dan daya saing antar sesama negara anggota ASEAN untuk menghadapi persaingan global. ${ }^{3}$

1 Aristeus, Syprianus. (2014). "Peluang Industri dan Perdagangan Indonesia Dalam Pelaksanaan Masyarakat Ekonomi ASEAN (Industry and Trade Opportunity of Indonesia on ASEAN Economic Community): Jurnal Rechtsvinding Media Pembinaan Hukum Nasional. 3(2): 146.

${ }^{2}$ Ibid., p. 146.

${ }^{3}$ Bappeda Kabupaten Malang. (2015). Kabupaten Malang menuju MEA 2015. Jawa Timur: Bappeda Kabupaten Malang, p. 2. 
Pembentukan MEA merupakan salah satu tujuan dari ASEAN. Dalam Piagam ASEAN, tujuan ini dirumuskan sebagai, To create a single market and production base which is stable, prosperous, highly competitive and economically integrated with effective facilitation for trade and investment in which there is free flow of goods, services and investment; facilitated movement of business persons, professionals, talents and labour; and free flow of capital. ${ }^{4}$ Pembentukan Masyarakat Ekonomi ASEAN tersebut tertuang dalam cetak Biru MEA 2015 yang ditandatangani tahun 2007 dibuat berdasarkan empat pilar, yaitu: ${ }^{5}$

Pilar 1: Pasar Tunggal dan Basis Produksi Pasar Tunggal

Melalui realisasi MEA, diharapkan ASEAN akan menjadi pasar tunggal dan basis produksi. Pembentukan ASEAN sebagai suatu pasar tunggal dan basis produksi akan membuat ASEAN lebih dinamis dan lebih berdaya saing dengan mekanisme dan langkah-langkah baru guna memperkuat pelaksanaan inisiatif-inisiatif ekonomi yang ada dalam mempercepat integrasi ekonomi sebagai rencana induk yang koheren dalam pembentukan MEA. Cetak Biru MEA mengidentifikasikan karakteristik dan elemen MEA dengan target dan batas waktu yang jelas untuk pelaksanaan berbagai tindakan yang disepakati untuk mengakomodasi kepentingan seluruh negara anggota ASEAN.

Dalam mendukung pembentukan ASEAN sebagai sebuah pasar tunggal dan basis produksi, maka hambatan perdagangan berupa tarif akan dihapuskan, dan hambatan non-tarif secara bertahap juga akan dihapus. Perdagangan dan sistem kepabeanan antar negara-negara di ASEAN akan terstandarisasi, sederhana dan harmonis sehingga diharapkan dapat mengurangi biaya transaksi. Selain itu, Kawasan ASEAN juga akan mengakomodir pergerakan bebas bagi para profesional, sedangkan Investor yang berminat berinvestasi di ASEAN juga akan diberikan kemudahan untuk berinvestasi di berbagai sektor, termasuk di sektor jasa. Pasar tunggal dan basis produksi ASEAN terdiri dari atas lima elemen inti, yaitu:

1. Arus barang yang bebas;

2. Arus jasa yang bebas;

3. Arus investasi yang bebas;

4. Arus modal yang lebih bebas;

5. Arus tenaga kerja terampil yang bebas.

Komponen dalam pasar tunggal dan basis produksi adalah termasuk 12 (dua belas) sektor-sektor prioritas integrasi, yakni: produk berbasis agro,

\footnotetext{
${ }^{4}$ Pasal 1 ayat (5) Piagam ASEAN.

${ }^{5}$ Direktorat Jenderal Kerja Sama Perdagangan Internasional. (2015). Menjadi Juara Di Era MEA 2015, Kementrian Perdagangan Republik Indonesia http://aeccenter.kemendag. go.id/media/177084/mea-2015-final-29-07-2015.pdf, (diunduh 1 Desember 2016).
} 
transportasi udara, otomotif, e-ASEAN, elektronika, perikanan, pelayanan kesehatan, produk berbasis karet, tekstil dan pakaian, pariwisata, produk berbasis kayu dan logistik, makanan, ditambah pertanian dan kehutanan.

Pilar 2: Kawasan Ekonomi yang Berdaya Saing

Perwujudan kawasan ekonomi yang stabil, makmur, dan berdaya saing tinggi merupakan tujuan dari integrasi ekonomi ASEAN. Terdapat enam elemen inti bagi kawasan ekonomi yang berdaya saing ini, yaitu: (i) Kebijakan persaingan; (ii) Pelindungan konsumen; (ii) Hak Kekayaan Intelektual (selanjutnya dapat disebut sebagai HKI); (iv) Pembangunan infrastruktur; (v) Perpajakan; dan (vi) e-commerce. Negara-negara anggota ASEAN telah berkomitmen untuk memperkenalkan kebijakan kawasan di sektor-sektor prioritas, memfasilitasi pergerakan para pelaku usaha, tenaga kerja terampil dan berbakat, dan memperkuat mekanisme kelembagaan ASEAN untuk menjadikan ASEAN sebuah kawasan ekonomi yang berdaya saing tinggi.

Pilar 3: Ekonomi yang Merata

Di bawah karakteristik ini terdapat dua elemen utama, yaitu: (i) Pengembangan Usaha Kecil dan Menengah (UKM); dan (ii) Inisiatif untuk Integrasi ASEAN. Kedua inisiatif ini diarahkan untuk menjembatani jurang pembangunan baik pada tingkat UKM maupun untuk memperkuat integrasi ekonomi Kamboja, Laos, Myanmar dan Vietnam (Kamboja, Laos, Myanmar, Vietnam/CLMV) agar semua anggota dapat bergerak maju secara serempak dan meningkatkan daya saing ASEAN sebagai kawasan yang memberikan manfaat dari proses integrasi kepada semua anggotanya.

Pilar 4: Integrasi dengan Ekonomi Global

ASEAN bergerak di sebuah lingkungan yang makin terhubung dalam jejaring global yang sangat terkait satu dengan yang lain, dengan pasar yang saling bergantung dan industri yang mendunia. Sehingga, agar pelaku usaha ASEAN dapat bersaing secara global, serta untuk menjadikan ASEAN lebih dinamis, maka diperlukan keseimbangan dalam pengembangan pasar domestik agar tetap menarik bagi investasi, serta pengembangan pasar luar negeri guna mendorong terciptanya lebih banyak sentra produksi di ASEAN. Untuk itu, diperlukan sebuah payung hukum yang dapat mengakomodir persaingan usaha yang adil untuk mendorong proses integrasi ekonomi kawasan ASEAN dengan perekonomian global.

Dua pendekatan yang ditempuh ASEAN dalam proses integrasi dengan perekonomian dunia adalah: (i) Pendekatan koheren menuju hubungan ekonomi eksternal melalui Perjanjian Perdagangan Bebas (Free Trade Area/FTA) dan kemitraan ekonomi yang lebih erat (Closer Economic Partnership/CEP); dan (ii) Partisipasi yang lebih kuat dalam jejaring pasokan global. Selain itu, ASEAN tengah mengikuti proses integrasi kawasan yang lebih luas dengan melibatkan RRT, Jepang, Korea, India, 
Selandia Baru, dan Australia. Hal ini dilakukan untuk memperkuat integrasi ekonomi di kawasan ASEAN yang saat ini di warnai dengan kerja sama baru diantaranya Trans Pacific Partnership (TPP), serta mulai bergulirnya inisiasi pembentukan Free Trade Area on Asia Pacific (FTAAP).

Dalam penulisan ini, penulis menekankan pada aspek pilar kedua yaitu kawasan ekonomi yang berdaya saing, dimana MEA yang akan memberikan peluang dan tantangan bagi perkembangan ekspor Indonesia kedepan terutama menyangkut daya saing perdagangan. Dalam sektor manufaktur dapat diambil contoh misalnya daya saing produk Indonesia dibandingkan dengan negara ASEAN lainnya di pasar tujuan utama produk Indonesia, berdasarkan hasil kajian termuktahir dari Kementrian Perdagangan Republik Indonesia, dimana terhadap posisi daya saing Indonesia di pasar dunia untuk masing-masing produk manufaktur ekspor secara berurutan adalah: ${ }^{6}$

1. Produk Mesin : Daya saing Indonesia masih kalah jika dibandingkan Thailand dan Singapura di 10 negara tujuan ekspor produk mesin Indonesia;

2. Produk Otomotif : Indonesia masih kalah jika dibandingkan dengan Philipina dan Thailand di 10 negara tujuan utama ekspor Indonesia;

3. Produk Kayu : Indonesia memiliki daya saing yang sangat baik jika dibandingkan dengan negara ASEAN lainnya. Malaysia dan Thailand berada pada urutan ke-2 dan ke-3 setelah Indonesia;

4. Produk Logam : Indonesia memiliki daya saing untuk produk logam di 10 negara tujuan ekspor utama, kemudian disusul oleh Philipina dan Thailand;

5. Produk Karet : Thailand merupakan negara yang memiliki daya saing yang baik untuk produk karet di 10 negara tujuan ekspor Indonesia. Sementara Indonesia berada di urutan ke-2 dan Malaysia berada pada urutan ke-3;

6. Produk Alas Kaki : Vietnam dan Indonesia merupakan negara yang sama-sama memiliki daya saing yang sangat baik untuk produk alas kaki di 10 negara tujuan ekspor Indonesia;

7. Produk Plastik : Thailand dan Singapura memiliki daya saing di hampir seluruh negara tujuan ekspor produk plastik Indonesia. Malaysia dan Vietnam berada di urutan ke-3 dan ke-4 setelah Thailand dan Singapura.

\footnotetext{
${ }^{6}$ Kementerian Perdagangan. (2015). Laporan Analisis Daya Saing Indonesia dan ASEAN Lainnya di Pasar Produk Utama Indonesia Pusat, Pusat Kebijakan Perdagangan Luar Negeri Badan Pengkajian dan Pengembangan Kebijakan Perdagangan Kementerian Perdagangan, Pustaka Daglu, http://www.kemendag.go.id/files/pdf/2016/06/15/analisisdaya-saing-1465976277.pdf, (diunduh 1 Desember 2016), pp. 117-119.
} 
Daya saing produk plastik Indonesia masih kalah jika dibandingkan dengan negara ASEAN lainnya;

8. Tekstil dan produk tekstil (TPT) : Indonesia dan Vietnam merupakan negara yang sama-sama memiliki daya saing yang kuat untuk tekstil dan produk tekstil;

9. Produk Elektronik: Malaysia, Filipina dan Singapura merupakan negara yang sama-sama memiliki daya saing yang baik untuk produk elektronik di 10 pasar tujuan ekspor elektronik Indonesia. Thailand dan Vietnam berada pada posisi ke-4 dan ke-5, sementara Indonesia masih kalah dbandingkan dengan negara ASEAN lainnya;

10.Produk kimia : Indonesia memiliki daya saing yang baik untuk produk kimia di 10 negara tujuan utama ekspor Indonesia, kemudian disusul oleh Singapura, Malaysia dan Thailand.

Kerjasama regional di bidang hak kekayaan intelektual khususnya merek juga terkait dengan ASEAN Intellectual Property Right ASEAN IPR Action plan (2011-2015). Adapun rencana aksi tersebut ditujukan untuk mengembangkan kreatifitas dan inovasi yang didukung oleh sistem pendaftaran merek yang lebih memberikan pelayanan terhadap dunia usaha, serta dapat meningkatkan jejaring dan koordinasi, peningkatan kapasitas, kepedulian masyarakat, serta kontribusi industri hak kekayaan intelektual khususnya perlindungan hukum merek terhadap peningkatan daya saing dan pembangunan.

Dengan demikian, untuk menyambut era MEA, perkembangan hukum merek bukan hanya untuk mendasarkan kepentingan hukum baik pidana maupun perdata semata tetapi juga kepentingan nasional. Pembaharuan hukum merupakan kesadaran Indonesia untuk menjadi bagian dari globalisasi dunia, sehingga dapat memberikan manfaat terbaik bagi perekonomian nasional. Dalam pembentukan Undang-Undang Dasar Negara Republik Indonesia Tahun 1945, alenia ke 4 menegaskan bahwa bagian dari tujuan pembentukan pemerintah Indonesia adalah untuk memajukan kesejahteraan umum, sehingga memerlukan pengembangan kewirausahaan baik mikro, kecil dan menengah. Selanjutnya, merek berperan sangat penting karena pada dasarnya untuk daya berbeda antara suatu barang dengan barang yang lain.

Keberadaan merek menjadi sangat penting untuk menunjukkan reputasi dari produk barang dan jasa. Dengan demikian, pembaharuan perlindungan merek terkait dengan hukum yang senantiasa mampu memenuhi perkembangan yang ada. Dengan demikian, untuk menyambut era MEA, perlu tercipta suatu sistem perlindungan hukum merek yang mendorong pertumbuhan ekonomi dan daya saing bangsa.

Selama kurang lebih 14 tahun berlakunya Undang-Undang Nomor 15 Tahun 2001 tentang Merek, tercatat masih terdapat kelemahan dan belum 
dapat menampung perkembangan kebutuhan praktek ataupun tuntutan pelayanan kebutuhan hukum kepada masyarakat. Oleh karena itu perbaikan dan penyempurnaan terhadap kelemahan ketentuan dalam Undang-undang Nomor 15 Tahun 2001 tentang Merek sangat diperlukan dan dimaksudkan untuk :

1. Lebih meningkatkan pelayanan kepada masyarakat pemohon pendaftaran Merek.

2. Lebih memberikan kemudahan kepada masyarakat dalam melakukan pendaftaran Merek, yakni dengan menyederhanakan proses dan prosedur pendaftaran Merek.

3. Lebih memberikan perlindungan hukum terhadap pemilik Merek terdaftar dari kemungkinan pelanggaran Merek yang dilakukan oleh pihak lain.

4. Menyesuaikan aturan hukum di bidang Merek dengan ketentuanketentuan internasional di bidang Merek yang telah diratifikasi dan atau diakselerasi oleh Indonesia. ${ }^{7}$

Pengembangan kekayaaan intelektual dari solusi teknologi tidak serta merta membuat orang untuk melupakan solusi yang lama, dan biasanya bahkan tidak menyebabkan solusi yang lebih tua harus ditarik dari suatu pasar: sebaliknya, meningkatkan persaingan, yang cenderung mengikis harga solusi tua dari waktu ke waktu. Kondisi tersebut dapat meningkatkan pilihan dan kesejahteraan konsumen. Tujuan hukum persaingan yang sehat adalah kompetisi itu sendiri. Tujuan inilah yang juga diinginkan dimana pada dasarnya bertujuan untuk melindungi konsumen dari pelaku usaha yang curang atau tidak beritikad baik dalam menjalankan usahanya, sehingga kekayaan intelektual tidak dilihat secara skeptis. ${ }^{8}$

Selanjutnya, menurut Wahyu Sasongko, indikasi geografis merupakan rezim hak kekayaan intelektual dengan unsur-unsur atau sifat tersendiri (sui generis). Dalam Perjanjian Trade Related Aspect of Intellectual Property Right (selanjutnya disebut dengan TRIPs) dinyatakan: for the purpose of this agreement. Berarti, unsur-unsur dalam definisi indikasi geografis merupakan sifat khas yang berbeda dan dapat dibedakan dengan rezim hak kekayaan intelektual lain. Setidaknya, ada empat unsur pokok indikasi geografis dalam Perjanjian TRIPs, yaitu, pertama, unsur nama geografis untuk mengidentivikasi, tidak bersifat mutlak tetapi relatif karena dapat menggunakan nama non-geografis; kedua, unsur wilayah dalam negara sebagai tempat produksi tidak identik dengan wilayah administratif namun

\footnotetext{
${ }^{7}$ Panitia Khusus RUU Tentang Merek. (2016). Laporan Singkat Panitia Khsusus (Pansus) RUU Tentang Merek, Rapat ke-5, http://www.dpr.go.id, (diunduh tanggal 20 Juni 2016).

8 Rahmawati, Debrina. et.al. Perlindungan Hukum Atas Indikasi Geografis (Studi Perbandingan Hukum Indonesia Dengan Australia), http://hukum.studentjournal.ub.ac.id/ index.php/hukum/article/download/1535/1283, (diakses 12 November 2016).
} 
disesuaikan dengan kondisi faktual; ketiga, unsur kepemilikan dalam indikasi geografis bukan merupakan hak individual (private right) tetapi hak komunal (communal right), maka Indikasi Geografis merupakan hak untuk menggunakan (right to use); dan keempat, unsur kualitas, reputasi, atau karakteristik lain yang bersifat alternatif, maka suatu barang sudah cukup memenuhi salah satu dari unsur tersebut. ${ }^{9}$

Landasan Filosofis diterapkan dalam Undang-Undang No. 20 Tahun 2016 tentang Merek dan Indikasi Geografis agar memiliki makna dan bermanfaat bagi kepentingan nasional. Walaupun Indonesia menjadi anggota Organisasi Perdagangan Dunia, dan meratifikasi beberapa konvensi internasional dibidang HKI, serta berkewajiban melindungi kepentingan pemilik Merek yang sebenarnya, dan beritikad baik dapat melindungi khalayak ramai terhadap tiruan atau pemalsuan barang-barang dan jasa yang membonceng suatu barang atau jasa yang sudah terkenal sebagai barang dan jasa yang bermutu baik dan unggul, landasan sosiologis dalam penyusunan naskah akademik yaitu pemerintah perlu menciptakan kebijakan iklim investasi yang kondusif dan kebijakan mengenai :

1. Penghargaan terhadap Merek lokal, agar dapat bersaing dengan merek asing;

2. Memotivasi masyarakat agar tumbuh sikap sadar terhadap merek-merek lokal untuk meningkatkan produksi dalam negeri

3. Menjamin kepastian hukum bagi pemilik Merek. ${ }^{10}$

Landasan Yuridis yaitu, dalam era perdagangan bebas, HKI merupakan faktor penting dalam menciptakan sistem perdagangan bebas yang adil, dimana hal tersebut sangat memegang peranan penting, terutama untuk melindungi khalayak ramai terhadap tiruan atau pemalsuan barangbarang danjasa yang membonceng suatu barang atau jasa yang sudah terkenal sebagai barang dan jasa yang bermutu baik dan unggul. Salah satu ketentuan dalam WTO adalah aspek-aspek dagang yang terkait dengan HKI atau Agreement on Trade Related Aspect of Intellectual Property Right (TRIPs). Persetujuan TRIPs merupakan persetujuan yang mengatur tentang aspek-aspek perdagangan yang mensyaratkan adanya perlindungan terhadap HKI yang merupakan standar internasional dan harus dipakai berkenaan dengan HKI, termasuk Merek. Sejak berlakunya UU No. 15 tahun 2001, dalam praktiknya masih ditemui kendala-kendala. UU No. 15 Tahun 2001 tidak sesuai dengan perkembangan kebutuhan hukum dalam masyarakat, dan

\footnotetext{
9 Sasongko, Wahyu. (2008). Indikasi Geografis: Rezim HKI Yang Bersifat Sui Generis, Jurnal Media Hukum, http://download.portalgaruda.org/article.php?article=98312\&val= 648, (diakses 10 September 2016), pp. 107-108.

${ }^{10}$ Badan Pembinaan Hukum Nasional. (2015). Naskah Akademik RUU tentang Merek 2015. Kementrian Hukum dan HAM Republik Indonesia, http://www.bphn.go.id/data/documents/ penyelarasan.na.ruu.tentang.merek.pdf, pp. 58-63.
} 
harus dirubah dengan melakukan penyesuaian dengan konvensi-konvensi di bidang Merek, baik yang sudah diratifikasi yaitu Persetujuan TRIPs, Konvensi Paris dan Trademark Law Treaty, maupun konvensi yang akan di ratifikasi, yaitu Protokol Madrid. ${ }^{11}$ Dengan demikian, penulis meninjau kesiapan Undang-Undang No. 20 Tahun 2016 tentang Merek dan Indikasi Geografis dalam memberikan perlindungan hukum yang sesuai dengan kondisi perekonomian masyarakat baik lokal maupun global dalam rangka menghadapi era MEA. Perspektif tentang ketentuan hukum merek inilah yang menjadi lingkup dari permasalahan yang akan diuraikan dalam penulisan ini, oleh karena itu, penulisan ini diberi judul: "Kesiapan UndangUndang No. 20 Tahun 2016 Tentang Merek dan Indikasi Geografis Dalam Menghadapi Masyarakat Ekonomi ASEAN".

Permasalahan dalam penelitian ini dirumuskan sebagai berikut:

1. Bagaimanakah pembaruan substansial perlindungan hukum merek dan indikasi geografis menurut Undang-Undang Nomor 20 Tahun 2016 tentang Merek dan Indikasi Geografis?

2. Bagaimanakah kesiapan Undang-Undang Nomor 20 Tahun 2016 tentang Merek dan Indikasi Geografis dalam menghadapi masyarakat ekonomi ASEAN?

Metode yang dipergunakan dalam penelitian ini adalah metode deskriptif analitis dan pendekatannya adalah yuridis normatif. Deskriptif analitis berarti menggambarkan dan melukiskan sesuatu yang menjadi obyek penelitian secara kritis melalui analisis yang bersifat kualitatif.

\section{B. Pembahasan}

\section{Pembaruan Substansial Perlindungan Hukum Merek Dan Indikasi Geografis Menurut Undang-Undang No. 20 Tahun 2016 tentang Merek dan Indikasi Geografis \\ a. Perluasan Definisi Merek}

Berdasarkan Pasal 1 Undang-Undang Nomor 15 Tahun 2001 tentang Merek, menyatakan bahwa Merek adalah tanda yang berupa gambar, nama, kata, huruf-huruf, angka-angka, susunan warna, atau kombinasi dari unsurunsur tersebut yang memiliki daya pembeda dan digunakan dalam kegiatan perdagangan barang atau jasa. Penjelasan unsur-unsurnya sebagai berikut. Sedangkan terdapat perluasan definisi merek dalam ketentuan undangundang yang baru, yaitu dalam Pasal 1 ayat 1 Undang-Undang No. 20 Tahun 2016 tentang Merek dan Indikasi Geografis menyatakan "Merek adalah tanda yang dapat ditampilkan secara grafis berupa gambar, logo, nama, kata, huruf, angka, susunan warna, dalam bentuk 2 (dua) dimensi dan/atau 3

${ }^{11}$ Ibid. 
(tiga) dimensi, suara, hologram, atau kombinasi dari 2 (dua) atau lebih unsur tersebut untuk membedakan barang dan/atau jasa yang diproduksi oleh orang atau badan hukum dalam kegiatan perdagangan barang dan/atau jasa". Selanjutnya dalam Pasal 2 Undang-Undang No. 20 Tahun 2016 tentang Merek dan Indikasi Geografis menyebutkan bahwa lingkup Undang-Undang ini meliputi merek dan indikasi geografis yang meliputi merek dagang dan merek jasa. Merek yang dilindungi terdiri atas tanda berupa gambar, logo, nama, kata, huruf, angka, susunan warna, dalam bentuk 2 (dua) dimensi dan/atau 3 (tiga) dimensi, suara, hologram, atau kombinasi dari 2 (dua) atau lebih unsur tersebut untuk membedakan barang dan/atau jasa yang diproduksi oleh orang atau badan hukum dalam kegiatan perdagangan barang dan/atau jasa.

\section{b. Permohonan Pendaftaran Merek Internasional}

Pasal 52 Undang-Undang No. 20 Tahun 2016 tentang Merek dan Indikasi Geografis mengenai ketentuan permohonan pendaftaran merek internasional menyebutkan:

(1) Permohonan pendaftaran Merek internasional dapat berupa:

a. Permohonan yang berasal dari Indonesia ditujukan ke biro internasional melalui Menteri; atau

b. Permohonan yang ditujukan ke Indonesia sebagai salah satu negara tujuan yang diterima oleh Menteri dari biro internasional.

(2) Permohonan pendaftaran Merek internasional sebagaimana dimaksud pada ayat (1) huruf a hanya dapat dimohonkan oleh:

a. Pemohon yang memiliki kewarganegaraan Indonesia;

b. Pemohon yang memiliki domisili atau tempat kedudukan hukum di wilayah Negara Kesatuan Republik Indonesia; atau

c. Pemohon yang memiliki kegiatan usaha industri atau komersial yang nyata di wilayah Negara Kesatuan Republik Indonesia.

(3)Pemohon sebagaimana dimaksud pada ayat (2) telah mengajukan Permohonan atau memiliki pendaftaran Merek di Indonesia sebagai dasar Permohonan pendaftaran Merek internasional.

(4) Ketentuan lebih lanjut mengenai pendaftaran Merek internasional berdasarkan Protocol Relating to the Madrid Agreement Concerning the Internasional Registration of Marks diatur dengan Peraturan Pemerintah.

Undang-Undang No. 20 Tahun 2016 tentang Merek dan Indikasi Geografis menambah ketentuan mengenai "Permohonan Pendaftaran Merek 
Internasional", yaitu mengenai: permohonan yang berasal dari Indonesia ditujukan ke Biro Internasional dan permohonan yang ditujukan ke Indonesia sebagai salah satu Negara tujuan dari Biro Internasional. Selanjutnya, ketentuan lebih lanjut mengenai pendaftaran Merek internasional berdasarkan Protocol Relating to the Madrid Agreement Concerning the Internasional Registration of Marks diatur dengan Peraturan Pemerintah.

\section{c. Ketentuan Mengenai Merek yang Tidak Dapat Didaftar dan Ditolak 1) Ketentuan Lama Pada Saat Berlakunya Undang-undang Nomor 15 Tahun 2001 tentang Merek}

Berdasarkan Pasal 5 Undang-Undang Nomor 15 Tahun 2001 tentang Merek, sebuah merek tidak dapat didaftar apabila merek yang dimohonkan tersebut mengandung salah satu unsur dibawah ini: Bertentangan dengan peraturan perundang-undangan yang berlaku, moralitas agama, kesusilaan, atau ketertiban umum tanda-tanda yang tidak memilkiki daya pembeda tanda yang menjadi milik umum merupakan keterangan atau berkaitan dengan barang atau jasa yang dimohonkan pendaftarannya.

Dengan demikian merek tidak dapat didaftar berdasarkan unsur sebagai berikut: ${ }^{12}$

a) Bertentangan dengan peraturan perundang-undangan yang berlaku, moralitas agama, kesusilaan, atau ketertiban umum

Tanda-tanda yang bertentangan dengan peraturan perundangundangan yang berlaku tidak dapat diterima sebagai merek, karenanya tidak dapat didaftar. Hanya tanda-tanda yang tidak bertentangan dengan peraturan perundang-undangan yang berlaku yang dapat diterima sebagai merek, selanjutnya dapat didaftar. Demikian pula dilarang pemakaian tanda-tanda yang menurut pandangan masyarakat tertentu bertentangan dengan moralitas agama, kesusilaan, atau ketertiban umum, terutama tanda-tanda yang dapat menimbulkan salah paham di kalangan pembeli. Dalam pengertian bertentangan dengan moralitas agama, kesusilaan, atau ketertiban umum adalah apabila penggunaan tanda tersebut dapat menyinggung perasaan, kesopanan, ketenteraman, dan keagamaan dari khalayak umum atau dari golongan masyarakat tertentu. Misalnya penggunaan tanda yang merupakan atau menyerupai nama Allah dan Rasul-Nya.

b) Tanda tanda yang tidak memiliki daya pembeda

12 Usman, Rachmadi. (2003). Hukum Hak dan Kekayaan Intelektual, Perlindungan dan Dimensi Hukumnya di Indonesia. Bandung: PT. Alumni, p. 329. 
Sesuai dengan sifat merek sebagai suatu tanda untuk membedakan produk barang atau jasa seseorang atau badan hukum dengan barang atau jasa sejenis orang lain atau badan hukum, maka tanda yang tidak memiliki daya pembeda tidak dapat diterima sebagai merek. Suatu tanda dianggap tidak memiliki daya pembeda apabila tanda tersebut teralu sederhana, seperti satu tanda garis atau tanda titik, ataupun teralu rumit sehingga tidak jelas. Misalnya, lukisan atau warna barangnya sendiri, atau lukisan botol atau kotak yang dipergunakan untuk barang tersebut. Anga-angka dan hurufhuruf juga tidak mempunyai daya pembedaan sebagai merek oleh karena lazim dipergunakan sebagai keterangan-keterangan mengenai barang yang bersangkutan.

c) Tanda-tanda yang bersifat umum dan menjadi milik umum juga tidak dapat diterima sebagai merek. Misalnya tanda tengkorak di atas dua tulang yang bersilang, yang secara umum diketahui sebagai tanda bahaya. Tanda seperti itu adalah tanda yang bersifat umum dan telah menjadi milik umum dan selayaknya tidak dapat dieprgunakan sebagai suatu tanda tertentu untuk keperluan pribadi seseorang. Demi kepentingan umum, tanda-tanda seeprti itu harus dapat dipergunakan secara bebas di dalam masyarakat. Oleh karena itu, tanda-tanda yang demikian tidak dapat digunakan sebagai merek.

d) Merupakan keterangan atau berkaitan dengan barang atau jasa yang dimohonkan pendaftarannya

Sebuah merek yang berisikan keterangan atau berkaitan dengan barang atau jasa yang akan dimohonkan pendaftarannya juga tidak dapat diterima untuk didaftar sebagai merek, karena keterangan tersebut tidak mempunyai daya pembeda. Misalnya, merek kopi atau gambar kopi untuk jenis barang kopi atau untuk produk kopi.

Menurut ketentuan yang berlaku, Pasal 6 Undang-Undang No. 15 Tahun 2001 tentang Merek yang ditolak pendaftarannya antara lain:

a) Mempunyai persamaan pada pokoknya atau keseluruhannya dengan Merek milik pihak lain yang sudah terdaftar lebih dahulu untuk barang dan/atau jasa yang sejenis;

Persamaan pada pokoknya disini adalah kemiripan yang disebabkan oleh adanya unsur-unsur yang menonjol antara merek yang satu dan merek yang lain, yang dapat menimbulkan kesan adanya persamaan baik mengenai bentuk, cara penempatan, cara penulisan atau kombinasi antara unsur-unsur ataupun persamaan bunyi ucapan yang terdapat dalam merek-merek tersebut yang bersangkutan.

b) Mempunyai persamaan pada pokoknya atau keseluruhannya dengan Merek yang sudah terkenal milik pihak lain untuk barang dan/atau jasa sejenis; 
Dalam menolak permohonan pendaftaran merek yang mempunyai persamaan pada pokoknya atau keseluruhan dengan merek terkenal untuk barang dan atau jasa yang sejenis, dilakukan dengan memperhatikan

(1) Pengetahuan umum masyarakat mengenai merek tersebut di bidang usaha yang bersangkutan

(2) Reputasi merek terkenal yang diperoleh karena promosi yang gnecar dan besar-besaran, investasi di beberapa negara di dunia yang dilakukan oleh pemiliknya dan disertai bukti pendaftaran merek tersebut di beberapa negara

Untuk menentukan apakah suatu merek ini merupakan merek terkenal, Pengadilan Niaga dapat memerintahkan lembaga yang bersifat mandiri untuk melakukan survei guna memperoleh kesimpulan mengenai terkenal atau tidaknya merek yang menjadi dasar penolakan

c) Mempunyai persamaan pada pokoknya atau keseluruhannya dengan indikasi-geografis yang sudah dikenal.

Permohonan pendaftaran merek juga harus ditolak oleh direktorat Jenderal HaKI, apabila merek tersebut: ${ }^{13}$

a) Merupakan atau menyerupai nama orang terkenal, foto, atau nama badan hukum yang digunakan sebagai merek dan terdaftar dalam Daftar Umum Merek yang dimiliki orang lain, kecuali atas persetujuan tertulis dari yang berhak

b) Merupakan tiruan atau menyerupai nama atau singkatan nama, bendera, lambang atau simbol emblem negara atau lembaga nasional (termasuk organisasi masyarakat ataupun organisasi sosial politik) maupun internasional kecuali atas persetujuan tertulis dari pihak yang berwenang

c) Merupakan tiruan atau menyerupai tanda atau cap atau stempel resmi yang digunakan oleh negara atau lembaga pemerintah, kecuali atas persetujuan tertulis dari pihak yang berwenang

Dengan demikian, tidak semua tanda dapat didaftar sebagai merek. Hanya tanda-tanda yang memenuhi syarat dibawah ini yang dapat didaftar sebagai merek yaitu:

a) Mempunyai daya pembeda

b) Merupakan tanda pada barang dagang atau jasa yang dapat berupa gambar, nama, kata, huruf-huruf, angka-angka, susunan warna atau kombinasi dari unsur tersebut

c) Tanda tersebut tidak bertentangan dengan peraturan perundang-undangan yang berlaku, moralitas agama, kesusilaan, atau ketertiban umum, bukan tanda bersifat umum dan tidak menjadi milik umum, atau bukan merupakan keterangan atau berkaitan dengan barang atau jasa yang dimohonkan pendaftarannya

${ }^{13}$ Ibid., p. 330. 
d) Tanda tersebut juga tidak mempunyai persamaan dengan merek lain yang terdaftar lebih dahulu, merek terkenal, atau indikasi geografis yang sudah dikenal

e) Tidak merupakan, menyerupai atau tiruan tanda lainnya yang dimiliki oleh suatu lembaga atau negara tertentu

\section{2) Ketentuan Baru Dalam Undang-Undang No. 20 Tahun 2016 tentang Merek dan Indikasi Geografis}

Terdapat perubahan mengenai merek yang tidak dapat didaftar dan ditolak berdasarkan Pasal 20 Undang-Undang No. 20 Tahun 2016 tentang Merek dan Indikasi Geografis, yaitu merek tidak dapat didaftar jika:

a) Bertentangan dengan ideologi negara, peraturan perundang-undangan, moralitas, agama, kesusilaan, atau ketertiban umum.

Penambahan kalimat "bertentangan dengan ideologi negara", dimana ideologi negara yaitu Pancasila yang berarti lima sila atau lima prinsip dasar untuk mencapai atau mewujudkan empat tujuan bernegara, antara lain (1) Ketuhanan Yang Maha Esa; (2) Kemanusiaan yang Adil dan Beradab; (3) Persatuan Indonesia; (4) Kerakyatan yang Dipimpin oleh Hikmat Kebijaksanaan dalam Permusyawaratan/Perwakilan; dan (5) Keadilan Sosial bagi Seluruh Rakyat Indonesia. Kelima sila tersebut untuk mewujudkan empat tujuan atau cita-cita ideal bernegara, yaitu: (1) melindungi segenap bangsa Indonesia dan seluruh tumpah darah Indonesia; (2) meningkatkan kesejahteraan umum; (3) mencerdaskan kehidupan bangsa; dan (4) ikut melaksanakan ketertiban dunia berdasarkan kemerdekaan, perdamaian yang abadi, dan keadilan sosial. Selanjutnya, yang dimaksud dengan "bertentangan dengan ketertiban umum" adalah tidak sejalan dengan peraturan yang ada dalam masyarakat yang sifatnya menyeluruh seperti menyinggung perasaan masyarakat atau golongan, menyinggung kesopanan. atau etika umum masyarakat, dan menyinggung ketentraman masyarakat atau golongan.

b) Sama dengan, berkaitan dengan, atau hanya menyebut barang dan/atau jasa yang dimohonkan pendaftarannya

Pada dasarnya ketentuan ini merupakan perubahan dari kalimat "merupakan keterangan atau berkaitan dengan barang atau jasa yang dimohonkan pendaftarannya", dimana merek tersebut berkaitan atau hanya menyebutkan barang dan/ atau jasa yang dimohonkan pendaftarannya.

c) Memuat unsur yang dapat menyesatkan masyarakat tentang asal, kualitas, jenis, ukuran, macam, tujuan penggunaan barang dan/atau jasa yang dimohonkan pendaftarannya atau merupakan nama varietas tanaman yang dilindungi untuk barang dan/atau jasa yang sejenis;

Yang dimaksud dengan "memuat unsur yang dapat menyesatkan" misalnya Merek "Kecap No. 1" tidak dapat didaftarkan karena menyesatkan 
masyarakat terkait dengan kualitas barang, merek "netto 100 gram" tidak dapat didaftarkan karena menyesatkan masyarakat terkait dengan ukuran barang.

d) Memuat keterangan yang tidak sesuai dengan kualitas, manfaat, atau khasiat dari barang dan/atau jasa yang diproduksi;

Yang dimaksud dengan "memuat keterangan yang tidak sesuai dengan kualitas, manfaat, atau khasiat dari barang dan/atau jasa yang diproduksi" adalah mencantumkan keterangan yang tidak sesuai dengan kualitas, manfaat, khasiat, dan/atau risiko dari produk dimaksud. Contohnya: obat yang dapat menyembuhkan seribu satu penyakit, rokok yang aman bagi kesehatan.

e) Tidak memiliki daya pembeda; dan/atau

Tanda dianggap tidak memiliki daya pembeda apabila tanda tersebut terlalu sederhana seperti satu tanda garis atau satu tanda titik, ataupun terlalu rumit sehingga tidak jelas.

f) Merupakan nama umum dan/atau lambang milik umum.

Yang dimaksud dengan "nama umum" antara lain Merek "rumah makan" untuk restoran, merek "warung kopi" untuk kafe. Adapun "lambang milik umum" antara lain "lambang tengkorak" untuk barang berbahaya, lambang "tanda racun" untuk bahan kimia, "lambang sendok dan garpu" untuk jasa restoran.

Sedangkan ketentuan mengenai merek yang ditolak didaftarkan terdapat dalam Pasal 21 Undang-Undang No. 20 Tahun 2016 tentang Merek dan Indikasi Geografis:

(1) Permohonan ditolak jika Merek tersebut mempunyai persamaan pada pokoknya atau keseluruhannya dengan:

a. Merek terdaftar milik pihak lain atau dimohonkan lebih dahulu oleh pihak lain untuk barang dan/atau jasa sejenis;

b. Merek terkenal milik pihak lain untuk barang dan/atau jasa sejenis;

c. Merek terkenal milik pihak lain untuk barang dan/atau jasa tidak sejenis yang memenuhi persyaratan tertentu; atau

d. Indikasi Geografis terdaftar.

(2) Permohonan ditolak jika Merek tersebut:

a. Merupakan atau menyerupai nama atau singkatan nama orang terkenal, foto, atau nama badan hukum yang dimiliki orang lain, kecuali atas persetujuan tertulis dari yang berhak;

b. Merupakan tiruan atau menyerupai nama atau singkatan nama, bendera, lambang atau simbol atau emblem suatu negara, atau lembaga nasional maupun internasional, kecuali atas persetujuan tertulis dari pihak yang berwenang; atau 
c. Merupakan tiruan atau menyerupai tanda atau cap atau stempel resmi yang digunakan oleh negara atau lembaga Pemerintah, kecuali atas persetujuan tertulis dari pihak yang berwenang.

(3) Permohonan ditolak jika diajukan oleh pemohon yang beritikad tidak baik.

(4) Ketentuan lebih lanjut mengenai penolakan permohonan. Merek sebagaimana dimaksud pada ayat (1) huruf a sampai dengan huruf c diatur dengan Peraturan Menteri.

Penjelasan terhadap merek terkenal yaitu penolakan permohonan yang mempunyai persamaan pada pokoknya atau keseluruhan dengan Merek terkenal milik pihak lain untuk barang dan/atau jasa yang sejenis dilakukan dengan memperhatikan pengetahuan umum masyarakat mengenai Merek tersebut di bidang usaha yang bersangkutan. Di samping itu, diperhatikan pula reputasi merek tersebut yang diperoleh karena promosi yang gencar dan besar-besaran, investasi di beberapa negara di dunia yang dilakukan oleh pemiliknya, dan disertai bukti pendaftaran Merek dimaksud di beberapa negara. Jika hal tersebut belum dianggap cukup, Pengadilan Niaga dapat memerintahkan lembaga yang bersifat mandiri untuk melakukan survei guna memperoleh kesimpulan mengenai terkenal atau tidaknya merek yang menjadi dasar penolakan.

Selanjutnya, kriteria merek terkenal berdasarkan Yurisprudensi Mahkamah Agung RI Nomor $1486 \mathrm{~K} / \mathrm{pdt} / 1991$ yang menyatakan bahwa : "Pengertian Merek terkenal yaitu, apabila suatu Merek telah beredar keluar dari batas-batas regional sampai batas-batas internasional, dimana telah beredar keluar negeri asalnya dan dibuktikan dengan adanya pendaftaran Merek yang bersangkutan di berbagai negara". Akan tetapi, menurut penulis masih terdapat subjektivitas yang tinggi dengan pengertian dan yurisprudensi tersebut. Apalagi menurut penjelasan dalam ketentuan perudang-undangan yang baru, dimana Pengadilan Niaga dapat memerintahkan lembaga yang bersifat mandiri untuk melakukan survei guna memperoleh kesimpulan mengenai terkenal atau tidaknya merek yang menjadi dasar penolakan. Seharusnya terdapat lembaga resmi negara yang dapat mensurvey secara resmi keterkenalan suatu merek. Lembaga resmi diperlukan untuk pembuktian secara objektif, bukan hanya alasan subjektif.

\section{d. Penyederhanaan Jangka Waktu Proses Pendaftaran}

Jangka waktu proses pendaftaran Merek dari yang sebelumnya 14 bulan 10 hari menjadi paling lama 9 bulan 15 hari, sehingga dengan perubahan ini dapat lebih efesien karena memangkas waktu dengan cukup signifikan, namun perlu tetap memberikan pelayan yang akuntabel dan akurat serta lebih baik kepada para pemohon pendaftaran merek. Perubahan 
ini dapat mendorong pengembangan perekonomian masyarakat dan iklim investai yang lebih kondusif. Selanjutnya, ketentuan permohonan banding terdapat dalam pasal 28, 29 dan 30 yang menyebutkan:

Pasal 28

(1) Permohonan banding dapat diajukan terhadap penolakan permohonan berdasarkan alasan sebagaimana dimaksud dalam Pasal 20 dan/atau Pasal 21.

(2) Permohonan banding diajukan secara tertulis oleh Pemohon atau Kuasanya kepada Komisi Banding Merek dengan tembusan yang disampaikan kepada Menteri dengan dikenai biaya.

(3) Permohonan banding diajukan dengan menguraikan secara lengkap keberatan serta alasan terhadap penolakan permohonan.

(4) Alasan sebagaimana dimaksud pada ayat (3) bukan merupakan perbaikan atau penyempurnaan atas Permohonan yang ditolak.

Pasal 29

(1) Permohonan banding terhadap penolakan permohonan diajukan dalam jangka waktu paling lama 90 (sembilan puluh) hari terhitung sejak tanggal pengiriman surat pemberitahuan penolakan permohonan.

(2) Dalam hal permohonan banding sebagaimana dimaksud pada ayat (1) tidak diajukan, penolakan permohonan dianggap diterima oleh Pemohon.

Pasal 30

(1) Keputusan Komisi Banding Merek diberikan dalam waktu paling lama 3 (tiga) bulan terhitung sejak tanggal penerimaan permohonan banding.

(2) Dalam hal Komisi Banding Merek mengabulkan permohonan banding, Menteri menerbitkan dan memberikan sertifikat Merek kepada Pemohon atau Kuasanya sebagaimana dimaksud dalam Pasal 24.

(3)Dalam hal Komisi Banding Merek menolak permohonan banding, Pemohon atau Kuasanya dapat mengajukan gugatan atas putusan penolakan permohonan banding kepada Pengadilan Niaga dalam waktu paling lama 3 (tiga) bulan terhitung sejak tanggal diterimanya keputusan penolakan tersebut.

(4) Terhadap putusan Pengadilan Niaga sebagaimana dimaksud pada ayat (3) dapat diajukan kasasi. 
Alur Proses pendaftaran Merek menurut Undang-Undang No. 20 Tahun 2016 tentang Merek dan Indikasi Geografis, yaitu:

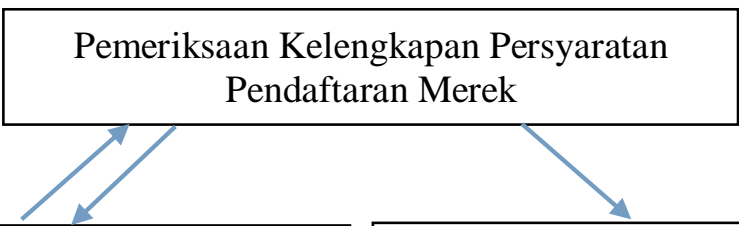

Terdapat kekurangan dalam kelengkapan persyaratan, maka harus memenuhi kelengkapan persyaratan tersebut paling lama 2 (dua) bulan (Pasal 11 ayat 2), atau 3 (tiga) bulan bagi pengajuan dengan hak prioritas (Pasal 11 ayat 3 ).
Menteri mengumumkan permohonan dalam Berita Resmi Merek dalam waktu paling lama 15 (lima belas) hari terhitung sejak tanggal penerimaan permohonan sebagaimana dimaksud dalam Pasal 13 (Pasal 14 ayat 1$)$. Permohonan dalam Berita Resmi Merek sebagaimana dimaksud pada ayat (1) berlangsung selama 2 (dua) bulan (Pasal 14 ayat 2).

\section{Keberatan dan Sanggahan}

Dalam hal terdapat keberatan maka dalam waktu paling lama 14 (empat belas) hari terhitung sejak tanggal penerimaan keberatan, salinan surat yang berisikan keberatan tersebut dikirimkan kepada Pemohon atau Kuasanya. (Pasal 16 ayat 3)
Sanggahan sebagaimana dimaksud pada ayat (1) diajukan secara tertulis dalam waktu paling lama 2 (dua) bulan terhitung sejak Tanggal Pengiriman salinan keberatan yang disampaikan oleh Menteri. (Pasal 17 ayat 2)

Dalam hal terdapat keberatan, dalam waktu paling lama 30 (tiga puluh) hari terhitung sejak tanggal berakhirnya batas waktu penyampaian sanggahan sebagaimana dimaksud dalam Pasal 17, dilakukan pemeriksaan substantif terhadap permohonan (Pasal 23 ayat 4) 
Dalam hal tidak terdapat keberatan, dalam waktu paling lama 30 (tiga puluh) hari terhitung sejak tanggal berakhirnya pengumuman, dilakukan pemeriksaan substantif terhadap permohonan (Pasal 23 ayat 3).

\begin{tabular}{|c|c|}
\hline $\begin{array}{l}\text { Pendaftaran merek } \\
\text { (Pasal 24) }\end{array}$ & $\begin{array}{l}\text { Pemeriksaan substantif } \\
\text { diselesaikan dalam jangka waktu } \\
\text { paling lama } 150 \text { (seratus lima } \\
\text { puluh) hari (Pasal } 23 \text { ayat } 5 \text { ). }\end{array}$ \\
\hline $\begin{array}{l}\text { Dalam hal Pemeriksa } \\
\text { memutuskan permohonan } \\
\text { tidak dapat didaftar atau } \\
\text { ditolak, Menteri } \\
\text { memberitahukan secara } \\
\text { tertulis kepada Pemohon } \\
\text { atau Kuasanya dengan } \\
\text { menyebutkan alasannya } \\
\text { (Pasal } 24 \text { ayat 4) }\end{array}$ & $\begin{array}{l}\text { Dalam jangka waktu paling lama } \\
30 \text { (tiga puluh) Hari terhitung } \\
\text { sejak tanggal pengiriman surat } \\
\text { pemberitahuan sebagaimana } \\
\text { dimaksud pada ayat (2), Pemohon } \\
\text { atau Kuasanya dapat } \\
\text { menyampaikan tanggapannya } \\
\text { secara tertulis dengan } \\
\text { menyebutkan alasannya (Pasal } 24\end{array}$ \\
\hline
\end{tabular}

\section{1) Ketentuan Mengenai Merek Generik}

Pengertian dari istilah "merek generik" adalah tanda yang telah menjadi generik atau telah masuk ke dalam penggunaan yang umum dalam perdagangan, maka seyogyanya harus ditolak pendaftarannya, dan juga dikatakan bahwa sebuah kata yang "ekslusif" dalam merek adalah penting, seperti uraian berikut: for sign which have become generic or have come into general use in the trade, to be refused the word 'exclusively' is important. ${ }^{14}$ Pengertian tersebut harus dibedakan dari istilah descriptive mark, yaitu bila suatu pihak mengadopsi nama atau tanda yang kata dalam bahasa yang biasa secara umum digunakan dan yang cenderung menggambarkan barang yang dijual. ${ }^{15}$

14 Morcom, Christopher. Et. al. (1999). The Modern Law of Trade Mark. London: Butterworths. p. 43.

${ }^{15}$ Erinaldi. (2012). Pemberian Hak Merek Generik dan Merek Deskriptif Dalam Pendaftaran Merek, Tesis Fakultas Hukum Program Studi Pasca Sarjana Universitas Indonesia. 
Pasal 22 Undang-Undang No. 20 Tahun 2016 tentang Merek dan Indikasi Geografis menyebutkan bahwa "Terhadap Merek terdaftar yang kemudian menjadi nama generik, setiap Orang dapat mengajukan Permohonan Merek dengan menggunakan nama generik dimaksud dengan tambahan kata lain sepanjang ada unsur pembeda". Dengan demikian, terkait dengan penggunaan merek yang sudah terdaftar dan kemudian menjadi sangat dikenal atau sangat umum/generik, sehingga dapat saja bagi setiap orang untuk mengajukan permohonan dengan merek generik tersebut dengan penambahan padanan kata, dengan catatan sepanjang ada unsur pembeda.

\section{2) Penarikan Sertifikat Merek Yang Tidak Diambil Pemiliknya}

Pasal 25 ayat (3) Undang-Undang No. 20 Tahun 2016 tentang Merek dan Indikasi Geografis, "Dalam hal sertifikat Merek yang telah diterbitkan tidak diambil oleh pemilik Merek atau Kuasanya dalam jangka waktu paling lama 18 (delapan belas) bulan terhitung sejak tanggal penerbitan sertifikat, Merek yang telah terdaftar dianggap ditarik kembali dan dihapuskan". Sejalan dengan prinsip bahwa pemegang merek tidak hanya boleh memonopoli suatu merek akan tetapi harus melakukan aktifitas dalam perdagangan barang/jasa, dengan kata lain memakai merek yang telah didaftarkan, maka terhadap merek-merek yang tidak digunakan dalam jangka waktu tertentu, maka akan dilakukan penghapusan merek terdaftar tersebut. Selanjutnya, terdapat ketentuan bahwa dalam hal sertifikat merek yang telah diterbitkan tidak diambil oleh pemiliknya dalam jangka waktu tertentu (satu sampai tiga tahun) maka merek tersebut dapat dianggap ditarik kembali dan merek tersebut dihapuskan.

\section{3) Perpanjangan Merek Terdaftar Berupa Logo}

Pasal 38 Undang-Undang Merek dan Desain Geografis menyebutkan:

(1) Perpanjangan Merek terdaftar yang berupa logo atau lambang perusahaan atau badan hukum, tidak memerlukan prosedur sebagaimana dimaksud dalam Pasal 35 sampai dengan Pasal 37, akan tetapi cukup dengan melakukan pembayaran biaya perpanjangan Merek terdaftar dalam jangka waktu 6 (enam) bulan sebelum berakhirnya jangka waktu perlindungan bagi merek terdaftar, sepanjang tidak terjadi sengketa terhadap perpanjangan Merek dimaksud.

(2)Dalam hal terjadi sengketa sebagaimana dimaksud pada ayat (1), penetapan pendaftaran permohonan perpanjangan merek ditetapkan setelah memiliki putusan yang berkekuatan hukum tetap. 
Pada dasarnya terkait dengan proses perpanjangan perlindungan merek terdaftar, dalam trakat internasional dibidang merek (trademark law treaty) terdapat ketentuan untuk tidak dilakukaannya pemeriksaan subtantif dalam proses perpanjangan. Akan tetapi, berdasarkan ketentuan dalam undang-undang baru ini, khusus terhadap merek terdaftar berupa logo atau lambang perusahaan atau badan hukum perpanjangan dapat berlaku secara otomatis setelah melakukan pembayaran.

\section{e. Tenaga Ahli Pemeriksa Merek Di Luar Pemeriksa}

Pasal 23 ayat 6, 7, dan 8 Undang-Undang No. 20 Tahun 2016 tentang Merek dan Indikasi Geografis menyebutkan:

(6) Dalam hal diperlukan untuk melakukan pemeriksaan substantif, dapat ditetapkan tenaga ahli pemeriksa Merek di luar Pemeriksa.

(7) Hasil pemeriksaan substantif yang dilakukan oleh tenaga ahli pemeriksa Merek di luar Pemeriksa sebagaimana dimaksud pada ayat (7), dapat dianggap sama dengan hasil pemeriksaan substantif yang dilakukan oleh Pemeriksa, dengan persetujuan Menteri.

(8) Ketentuan lebih lanjut mengenai tenaga ahli pemeriksa Merek di luar Pemeriksa sebagaimana dimaksud pada ayat (7) diatur dengan Peraturan Menteri.

Dalam rangka mempercepat penyelesaian proses permohonan pendaftaran merek maka menurut naskah akademik RUU Merek maka perlu juga untuk menetapkan tenaga ahli pemeriksa merek di luar pemeriksa fungsional, hal ini juga dimaksudkan untuk mengatasi ketidakseimbangan antara jumlah permohonan dan jumlah tenaga pemeriksa merek.

\section{f. Perbaikan atau Koreksi yang Dilakukan pada Permohonan Merek}

Ketentuan perbaikan dan penarikan kembali permohonan pendaftaran merek dalam bagian ketujuh mengenai perbaikan dan penarikan kembali permohonan pendaftaran merek, yaitu:

Pasal 18

Perbaikan atas Permohonan hanya diperbolehkan terhadap penulisan nama dan/atau alamat Pemohon atau Kuasanya.

Pasal 19

(1) Selama belum diterbitkannya sertifikat Merek atau surat penolakan dari Menteri, Permohonan dapat ditarik kembali oleh Pemohon atau Kuasanya.

(2) Dalam hal penarikan kembali sebagaimana dimaksud pada ayat (1) dilakukan oleh Kuasanya, penarikan itu harus 
dilakukan berdasarkan surat kuasa khusus untuk keperluan penarikan kembali tersebut.

Berdasarkan Undang-Undang No. 15 Tahun 2001, Permohonan Merek yang sudah diajukan tidak dapat dilakukan perubahan atau koreksi, kecuali Permohonan Merek sudah terdaftar. Dalam Undang-Undang No. 20 Tahun 2016 tentang Merek dan Indikasi Geografis, perbaikan atau koreksi dapat dilakukan terhadap permohonan pendaftaran merek.

\section{g. Perubahan Nama dan/atau Alamat Pemilik Merek Dapat Dilakukan Pada Saat Proses Permohonan Pendaftaran Merek}

Pasal 40 Undang-Undang No. 20 Tahun 2016 tentang Merek dan Indikasi Geografis mengenai perubahan perubahan nama dan/atau alamat pemilik Merek, menyebutkan:

(1) Permohonan pencatatan perubahan nama dan/atau alamat pemilik Merek terdaftar diajukan kepada Menteri dengan dikenai biaya untuk dicatat dengan disertai salinan yang sah mengenai bukti perubahan tersebut.

(2) Perubahan nama dan/atau alamat sebagaimana dimaksud pada ayat (1) dapat dilakukan pada saat proses Permohonan pendaftaran Merek.

(3) Perubahan nama dan/atau alamat pemilik Merek sebagaimana dimaksud pada ayat (1) diumumkan dalam Berita Resmi Merek.

(4) Ketentuan lebih lanjut mengenai syarat dan tata cara permohonan pencatatan perubahan nama dan/atau alamat sebagaimana dimaksud pada ayat (1) sampai dengan ayat (3) diatur dengan Peraturan Menteri.

Dalam Undang-Undang No. 15 Tahun 2001, ketentuan mengenai perubahan Nama/Alamat/Pengalihan Hak baru dapat dilakukan setelah permohonan Merek sudah terdaftar. Sedangkan, dalam Undang-Undang No. 20 Tahun 2016 tentang Merek dan Indikasi Geografis, perubahan nama dan/atau alamat dapat dilakukan pada saat proses permohonan pendaftaran Merek. Hal ini untuk menyesuaikan dengan ketentuan-ketentuan Trademark Law Treaty yang telah diratifikasi yaitu perubahan Nama/Alamat/Pengalihan Hak dapat diajukan pada tahap proses permohonan Merek.

\section{h. Ketentuan Biaya dan Denda Perpanjangan Jangka Waktu Perlindungan Merek}

Ketentuan mengenai jangka waktu perlindungan dan perpanjangan merek terdaftar dalam Pasal 35 Undang-Undang No. 20 Tahun 2016 tentang Merek dan Indikasi Geografis, menyebutkan: 
(1) Merek terdaftar mendapat perlindungan hukum untuk jangka waktu 10 (sepuluh) tahun sejak tanggal penerimaan.

(2) Jangka waktu pelindungan sebagaimana dimaksud pada ayat (1) dapat diperpanjang untuk jangka waktu yang sama.

(3) Permohonan perpanjangan sebagaimana dimaksud pada ayat (2) diajukan secara elektronik atau non-elektronik dalam bahasa Indonesia oleh pemilik merek atau Kuasanya dalam jangka waktu 6 (enam) bulan sebelum berakhirnya jangka waktu pelindungan bagi merek terdaftar tersebut dengan dikenai biaya.

(4) Permohonan perpanjangan sebagaimana dimaksud pada ayat (2) masih dapat diajukan dalam jangka waktu paling lama 6 (enam) bulan setelah berakhirnya jangka waktu perlindungan merek terdaftar tersebut dengan dikenai biaya dan denda sebesar biaya perpanjangan.

Berdasarkan Undang-Undang No. 15 Tahun 2001, permohonan perpanjangan jangka waktu perlindungan Merek dapat diajukan dalam batas waktu 12 bulan sebelum jangka waktu perlindungan berakhir. Jangka waktu untuk mengajukan permohonan perpanjangan Merek diubah menjadi 6 bulan sebelum jangka waktu perlindungan merek berakhir. Akan tetapi, perpanjangan merek juga masih dapat dilakukan oleh pemilik merek terdaftar dalam jangka waktu 6 bulan setelah tanggal berakhirnya jangka waktu perlindungan merek, dengan syarat bahwa Pemohon harus dikenakan pembayaran denda.

\section{i. Perlindungan Indikasi Geografis}

Ketentuan mengenai Indikasi Geografis terdapat BAB VIII Indikasi Geografis, ketentuan umum Pasal 53 Undang-Undang No. 20 Tahun 2016 tentang Merek dan Indikasi Geografis menyebutkan:

(1) Indikasi Geografis dilindungi setelah Indikasi Geografis didaftar oleh Menteri.

(2) Untuk memperoleh pelindungan sebagaimana dimaksud pada ayat (1), Pemohon Indikasi Geografis harus mengajukan Permohonan kepada Menteri.

(3) Pemohon sebagaimana dimaksud pada ayat (2) merupakan:

a. Lembaga yang mewakili masyarakat di kawasan geografis tertentu yang mengusahakan suatu barang dan/atau produk berupa:

1. Sumber daya alam;

2. Barang kerajinan tangan; atau

3. Hasil industri. 


\section{b. Pemerintah daerah provinsi atau kabupaten/kota.}

(4) Ketentuan mengenai pengumuman, keberatan, sanggahan, dan penarikan kembali sebagaimana dimaksud dalam Pasal 14 sampai dengan Pasal 19 berlaku secara mutatis mutandis bagi permohonan pendaftaran Indikasi Geografis.

Pasal 54

(1) Permohonan yang diajukan oleh Pemohon yang bertempat tinggal atau berkedudukan tetap di luar wilayah Negara Kesatuan Republik Indonesia wajib diajukan melalui Kuasanya di Indonesia.

(2) Permohonan sebagaimana dimaksud pada ayat (1) hanya dapat didaftar apabila Indikasi Geografis tersebut telah memperoleh pengakuan dari pemerintah negaranya dan/atau terdaftar sesuai dengan ketentuan yang berlaku di negara asalnya.

Pasal 55

(1) Indikasi Geografis dapat pula didaftarkan berdasarkan perjanjian internasional.

(2) Ketentuan lebih lanjut mengenai pendaftaran Indikasi Geografis dari luar negeri sebagaimana dimaksud dalam Pasal 54 diatur dengan Peraturan Menteri.

Pendaftaran indikasi geografis dalam Undang-Undang No. 20 Tahun 2016 tentang Merek dan Indikasi Geografis dapat dilakukan dari dalam maupun dari luar Negara Kesatuan Republik Indonesia. Permohonan yang diajukan oleh Pemohon yang bertempat tinggal atau berkedudukan tetap di luar wilayah Negara Kesatuan Republik Indonesia wajib diajukan melalui Kuasanya di Indonesia. Permohonan tersebut hanya dapat didaftar apabila Indikasi Geografis tersebut telah memperoleh pengakuan dari pemerintah negaranya dan/atau terdaftar sesuai dengan ketentuan yang berlaku di negara asalnya. Sementara permohonan indikasi geografis dari dalam negeri dapat pula didaftarkan berdasarkan perjanjian internasional. ${ }^{16}$

\section{j. Ketentuan Mengenai Indikasi Asal}

Ketentuan Indikasi Asal dalam Undang-Undang No. 20 Tahun 2016 tentang Merek dan Indikasi Geografis yaitu

Pasal 63

Indikasi asal dilindungi tanpa melalui kewajiban pendaftaran atau secara deklaratif sebagai tanda yang menunjukkan asal suatu barang dan/atau jasa yang benar dan dipakai dalam perdagangan. Pasal 64

\footnotetext{
${ }^{16}$ Panitia Khusus RUU Tentang Merek. (2016). Laporan Singkat Panitia Khsusus (Pansus) RUU Tentang Merek, Rapat ke-51.
} 
Indikasi asal merupakan ciri asal barang dan/atau jasa yang tidak secara langsung terkait dengan faktor alam.

Pasal 65

Ketentuan lebih lanjut mengenai indikasi asal sebagaimana dimaksud dalam Pasal 63 dan Pasal 64 diatur dengan Peraturan Menteri.

Menurut penjelasan Pasal 64, indikasi asal tidak sama dengan Indikasi Geografis karena indikasi asal hanya mengidentifikasi asal barang itu diproduksi yang tidak terkait dengan faktor alam. Hak indikasi asal timbul sejalan dengan perwujudan objek dan bukan melalui pendaftaran, berbeda dengan pelindungan Indikasi Geografis yang bersifat konstitutif dan mewajibkan pendaftaran.

\section{k. Penggunaan Media Elektronik Atau Non- Elektronik}

Ketentuan menurut Undang-Undang No. 20 Tahun 2016 tentang Merek dan Indikasi Geografis mengenai penggunaan media elektronik atau non-elektronik, antara lain:

Pasal 1 ayat (21)

"Tanggal Pengiriman adalah tanggal stempel pos dan/atau tanggal pengiriman surat secara elektronik"

Pasal 1 ayat (24)

Berita Resmi Merek adalah media resmi yang diterbitkan secara berkala oleh Menteri melalui sarana elektronik dan/atau nonelektronik dan memuat ketentuan mengenai Merek menurut Undang-Undang ini.

Pasal 4 ayat (1)

Permohonan pendaftaran Merek diajukan oleh Pemohon atau Kuasanya kepada Menteri secara elektronik atau non-elektronik dalam bahasa Indonesia.

Pasal 14 ayat (3)

Berita Resmi Merek sebagaimana dimaksud pada ayat (2) diterbitkan secara berkala oleh Menteri melalui sarana elektronik dan/atau non-elektronik.

Pasal 24 ayat (1) poin d

Dalam hal Pemeriksa memutuskan Permohonan dapat didaftar, Menteri mengumumkan pendaftaran Merek tersebut dalam Berita Resmi Merek, baik elektronik maupun non-elektronik.

Pasal 35 ayat (3)

Permohonan perpanjangan sebagaimana dimaksud pada ayat (2) diajukan secara elektronik atau non-elektronik dalam bahasa Indonesia oleh pemilik Merek atau Kuasanya dalam jangka waktu 
6 (enam) bulan sebelum berakhirnya jangka waktu perlindungan bagi Merek terdaftar tersebut dengan dikenai biaya.

\section{Pembinaan dan Pengawasan Indikasi Geografis}

Pembinaan dan Pengawasan Indikasi Geografis diatur dalam Pasal 70 dan 71 Undang-Undang No. 20 Tahun 2016 tentang Merek dan Indikasi Geografis, yaitu:

Pasal 70

(1) Pembinaan Indikasi Geografis dilakukan oleh pemerintah pusat dan/atau pemerintah daerah sesuai dengan kewenangannya.

(2) Pembinaan sebagaimana dimaksud pada ayat (1) meliputi:

a. Persiapan untuk pemenuhan persyaratan Permohonan Indikasi Geografis;

b. Permohonan pendaftaran Indikasi Geografis;

c. Pemanfaatan dan komersialisasi Indikasi Geografis;

d. Melakukan sosialisasi dan pemahaman atas perlindungan Indikasi Geografis;

e. Melakukan pemetaan dan inventarisasi potensi produk Indikasi Geografis;

f. Melakukan pelatihan dan pendampingan;

g. Pemantauan, evaluasi, dan pembinaan;

h. Memberikan pelindungan hukum; dan

i. Memfasilitasi pengembangan, pengolahan, dan pemasaran produk Indikasi Geografis.

Pasal 71

(1) Pengawasan Indikasi Geografis dilakukan oleh pemerintah pusat dan pemerintah daerah sesuai dengan kewenangannya.

(2) Pengawasan sebagaimana dimaksud pada ayat (1) dapat pula dilakukan oleh masyarakat.

(3) Pengawasan sebagaimana dimaksud pada ayat (1) dan ayat (2) dilakukan untuk:

a. Menjamin tetap adanya reputasi, kualitas, dan karakteristik yang menjadi dasar diterbitkannya Indikasi Geografis; dan b. Mencegah penggunaan Indikasi Geografis secara tidak sah.

(4) Hasil pengawasan sebagaimana dimaksud pada ayat (2) disampaikan kepada pemilik Indikasi Geografis dan/atau Menteri.

(5) Ketentuan lebih lanjut mengenai pengawasan sebagaimana dimaksud pada ayat (1) sampai dengan ayat (4) diatur dalam Peraturan Menteri. 


\section{m. Penghapusan Dan Pembatalan Pendaftaran Merek \\ 1) Penghapusan Merek Terdaftar}

Penghapusan merek terdaftar dapat dilakukan antara lain:

a) Atas Prakasa Pemilik Merek

Ketentuan Pasal 72 ayat 1 sampai 5 Undang-Undang No. 20 Tahun 2016 tentang Merek dan Indikasi Geografis menyatakan bahwa penghapusan Merek terdaftar dapat diajukan oleh pemilik Merek yang bersangkutan kepada Menteri. Permohonan penghapusan dapat diajukan oleh pemilik Merek atau melalui Kuasanya, baik untuk sebagian maupun seluruh jenis barang dan/atau jasa. Dalam hal Merek masih terikat perjanjian Lisensi, penghapusan hanya dapat dilakukan jika hal tersebut disetujui secara tertulis oleh penerima Lisensi. Pengecualian atas persetujuan hanya dimungkinkan jika dalam perjanjian Lisensi, penerima Lisensi dengan tegas menyetujui untuk mengesampingkan adanya persetujuan tersebut. Penghapusan pendaftaran Merek dicatat dan diumumkan dalam Berita Resmi Merek.

b) Atas Prakasa Menteri

Ketentuan Pasal 72 ayat 6 sampai 9 Undang-Undang No. 20 Tahun 2016 tentang Merek dan Indikasi Geografis menyatakan penghapusan Merek terdaftar dapat dilakukan atas prakarsa Menteri, yang dapat dilakukan jika:

(1) Memiliki persamaan pada pokoknya dan/atau keseluruhannya dengan Indikasi Geografis;

(2) Bertentangan dengan ideologi negara, peraturan perundang-undangan, moralitas, agama, kesusilaan, dan ketertiban umum; atau

(3) Memiliki kesamaan pada keseluruhannya dengan ekspresi budaya tradisional, warisan budaya tak benda, atau nama atau logo yang sudah merupakan tradisi turun temurun.

Penghapusan sebagaimana dimaksud dapat dilakukan setelah mendapatkan rekomendasi dari Komisi Banding Merek. Komisi Banding Merek memberikan rekomendasi berdasarkan permintaan Menteri. Selanjutnya Pasal 73 menyatakan

(1)Pemilik Merek yang keberatan terhadap keputusan penghapusan Merek terdaftar atas prakarsa Menteri sebagaimana dimaksud dalam Pasal 72 ayat (6) dan ayat (7) dapat mengajukan gugatan melalui Pengadilan Tata Usaha Negara.

(2) Pihak yang keberatan terhadap putusan Pengadilan Tata Usaha Negara sebagaimana dimaksud pada ayat (1) hanya dapat mengajukan kasasi ke Mahkamah Agung. 
c) Atas Prakasa Pihak Ketiga

Pasal 74 Undang-Undang Merek dan Indikasi mengatakan bahwa penghapusan Merek terdaftar dapat pula diajukan oleh pihak ketiga yang berkepentingan dalam bentuk gugatan ke Pengadilan Niaga dengan alasan Merek tersebut tidak digunakan selama 3 (tiga) tahun berturut-turut dalam perdagangan barang dan/atau jasa sejak tanggal pendaftaran atau pemakaian terakhir. Alasan Merek tidak digunakan sebagaimana dimaksud pada ayat tidak berlaku dalam hal adanya:

(1) Larangan impor;

(2) Larangan yang berkaitan dengan izin bagi peredaran barang yang menggunakan merek yang bersangkutan atau keputusan dari pihak yang berwenang yang bersifat sementara; atau

(3) Larangan serupa lainnya yang ditetapkan dengan peraturan pemerintah.

Penghapusan Merek terdaftar sebagaimana dimaksud pada ayat (1) dicatat dan diumumkan dalam Berita Resmi Merek. Ketentuan sebagaimana dimaksud dalam Pasal 74 berlaku secara mutatis mutandis terhadap penghapusan merek kolektif terdaftar. Selanjutnya, mengenai ketentuan bahwa penghapusan merek tersebut apabila tidak digunakan selama 3 (tiga) tahun berturut-turut dalam perdagangan barang dan/atau jasa sejak tanggal pendaftaran atau pemakaian terakhir, dalam praktik merek, alasan untuk menghapus suatu pendaftaran merek atas dasar non use pembuktiannya sulit. Oleh karena itu, diperlukan institusi resmi yang dapat memutuskan apabila merek tidak dipergunakan berturut-turut selama 3 (tiga) tahun atau lebih dalam perdagangan barang atau jasa sejak tanggal pendaftaran atau pemakaian terakhir. Lembaga resmi diperlukan untuk pembuktian secara objektif, bukan hanya alasan subjektif.

\section{2) Pembatalan Merek Terdaftar}

Pasal 76

(1) Gugatan pembatalan Merek terdaftar dapat diajukan oleh pihak yang berkepentingan berdasarkan alasan sebagaimana dimaksud dalam Pasal 20 dan/atau Pasal 21.

(2) Pemilik Merek yang tidak terdaftar dapat mengajukan gugatan sebagaimana dimaksud pada ayat (1) setelah mengajukan permohonan kepada Menteri.

(3)Gugatan pembatalan diajukan kepada Pengadilan Niaga terhadap pemilik Merek terdaftar.

Selanjutnya, gugatan pembatalan pendaftaran merek hanya dapat diajukan dalam jangka waktu 5 (lima) tahun terhitung sejak tanggal pendaftaran merek. Akan tetapi, gugatan pembatalan dapat diajukan tanpa batas waktu jika terdapat unsur iktikad tidak baik dan/atau merek yang bersangkutan bertentangan dengan ideologi negara, peraturan perundang- 
undangan, moralitas, agama, kesusilaan, dan ketertiban umum. Terhadap putusan Pengadilan Niaga atas gugatan pembatalan sebagaimana dimaksud dalam Pasal 76 ayat (3) dapat diajukan kasasi. Panitera pengadilan segera menyampaikan putusan kepada para pihak yang bersengketa. Ketentuan mengenai alasan gugatan pembatalan sebagaimana dimaksud dalam Pasal 76 berlaku secara mutatis mutandis terhadap Merek Kolektif terdaftar.

\section{n. Ketentuan Penyelesaian Sengketa}

Gugatan atas pelanggaran merek Pasal 83 dan Pasal 84 UndangUndang No. 20 Tahun 2016 tentang merek dan Indikasi Geografis. Gugatan dapat pula diajukan oleh pemilik merek terkenal berdasarkan putusan pengadilan, serta gugatan diajukan kepada Pengadilan Niaga. Pemilik merek terdaftar dan/atau penerima Lisensi Merek terdaftar dapat mengajukan gugatan terhadap pihak lain yang secara tanpa hak menggunakan Merek yang mempunyai persamaan pada pokoknya atau keseluruhannya untuk barang dan/atau jasa yang sejenis berupa:

1) Gugatan ganti rugi; dan/atau

2) Penghentian semua perbuatan yang berkaitan dengan penggunaan Mmerek tersebut.

Selanjutnya, ketentuan Pasal 84 menyatakan

(1) Selama masih dalam pemeriksaan dan untuk mencegah kerugian yang lebih besar, pemilik merek dan/atau penerima Lisensi selaku penggugat dapat mengajukan permohonan kepada hakim untuk menghentikan kegiatan produksi, peredaran, dan/atau perdagangan barang dan/atau jasa yang menggunakan Merek tersebut secara tanpa hak.

(2) Dalam hal tergugat dituntut menyerahkan barang yang menggunakan merek secara tanpa hak, hakim dapat memerintahkan penyerahan barang atau nilai barang tersebut dilaksanakan setelah putusan pengadilan mempunyai kekuatan hukum tetap.

Terkait dengan Alternatif Penyelesaian Sengketa, diatur dalam Pasal 93 yang menyebutkan: "Selain penyelesaian gugatan sebagaimana dimaksud dalam Pasal 83 para pihak dapat menyelesaikan sengketa melalui arbitrase atau alternatif penyelesaian sengketa". Selain penyelesaian sengketa di Pengadilan Niaga, dalam Undang-Undang No. 20 Tahun 2016 tentang Merek dan Indikasi Geografis dimungkinkan adanya upaya alternatif di luar pengadilan. Artinya para pihak yang bersengketa juga dapat menyelesaikan sengketa melalui jalur arbitrase atau alternatif penyelesaian sengketa. Alternatif penyelesaian sengketa adalah lembaga penyelesaian sengketa melalui prosedur yang dilakukan di luar pengadilan, dimana 
mekanismenya diserahkan sepenuhnya kepada para pihak yang bersengketa. Prosedur tersebut dapat berupa mediasi, negosiasi, konsiliasi, dan cara lain yang dipilih oleh para pihak yang bersengketa. ${ }^{17}$

Selanjutnya, ketentuan perdata mengenai gugatan perdata berdasarkan perbuatan curang atas merek terkenal, dalam Pasal 83 ayat 2 UndangUndang No. 20 Tahun 2016 tentang Merek dan Indikasi Geografis menyatakan "Gugatan sebagaimana dimaksud pada ayat (1) dapat pula diajukan oleh pemilik Merek terkenal berdasarkan putusan pengadilan". Penjelasan pasal tersebut menyatakan "Pemberian hak untuk mengajukan gugatan perdata berdasarkan perbuatan curang yang dilakukan oleh pihak lain dimaksudkan untuk memberikan pelindungan hukum kepada pemilik Merek terkenal meskipun belum terdaftar". Dengan demikian, pada bagian penyelesaian sengketa, Bagian Gugatan atas Pelanggaran Merek ditambah dengan ketentuan bahwa gugatan dapat pula diajukan oleh pemilik Merek terkenal berdasarkan putusan pengadilan.

\section{o. Ketentuan Pidana}

Ketentuan Pidana dalam Pasal 100 Undang-Undang No. 20 Tahun 2016 tentang Merek dan Indikasi Geografis menyebutkan:

(1) Setiap Orang yang dengan tanpa hak menggunakan Merek yang sama pada keseluruhannya dengan Merek terdaftar milik pihak lain untuk barang dan/atau jasa sejenis yang diproduksi dan/atau diperdagangkan, dipidana dengan pidana penjara paling lama 5 (lima) tahun dan/atau pidana denda paling banyak Rp2.000.000.000,00 (dua miliar rupiah).

(2) Setiap Orang yang dengan tanpa hak menggunakan Merek yang mempunyai persamaan pada pokoknya dengan Merek terdaftar milik pihak lain untuk barang dan/atau jasa sejenis yang diproduksi dan/atau diperdagangkan, dipidana dengan pidana penjara paling lama 4 (empat) tahun dan/atau denda paling banyak Rp2.000.000.000,00 (dua miliar rupiah).

(4) Setiap Orang yang melanggar ketentuan sebagaimana dimaksud pada ayat (1) dan ayat (2), yang jenis barangnya mengakibatkan gangguan kesehatan, gangguan lingkungan hidup, dan/atau kematian manusia, dipidana dengan pidana penjara paling lama 10 (sepuluh) tahun dan/atau denda paling banyak Rp5.000.000.000,00 (lima miliar rupiah).

Pasal 101

(1) Setiap Orang yang dengan tanpa hak menggunakan tanda yang mempunyai persamaan pada keseluruhan dengan Indikasi

${ }^{17}$ Ibid. 
Geografis milik pihak lain untuk barang yang sama atau sejenis dengan barang yang terdaftar, dipidana dengan pidana penjara paling lama 4 (empat) tahun dan/atau denda paling banyak Rp.2.000.000.000,00 (dua miliar rupiah).

(2) Setiap Orang yang dengan tanpa hak menggunakan tanda yang mempunyai persamaan pada pokoknya dengan Indikasi Geografis milik pihak lain untuk barang yang sama atau sejenis dengan barang yang terdaftar, dipidana dengan pidana penjara paling lama 4 (empat) tahun dan/atau denda paling banyak Rp2.000.000.000,00 (dua miliar rupiah).

Pasal 102

Setiap Orang yang memperdagangkan barang dan/atau jasa yang diketahui atau patut diduga mengetahui bahwa barang dan/atau jasa tersebut merupakan hasil tindak pidana sebagaimana dimaksud dalam Pasal 100 dan Pasal 101 dipidana dengan pidana kurungan paling lama 1 (satu) tahun atau denda paling banyak Rp200.000.000,00 (dua ratus juta rupiah).

Pasal 103

Tindak pidana sebagaimana dimaksud dalam Pasal 100 sampai dengan Pasal 102 merupakan delik aduan.

Menurut Naskah Akademik RUU Merek sekaligus pendapat penulis, dengan menjamurnya pemalsuan-pemalsuan merek, maka Undang-Undang tentang Merek harus memberikan kepastian hukum, sehingga pemalsuan harus dapat diatasi, hal ini untuk mendorong dan menggerakan perekonomian bangsa. Terkait dengan penegakan hukum pengakomodasikan ketentuan tindak pidana merek yang mengancam kesehatan dan atau keselamatan jiwa manusia dan lingkungan hidup patut diapresiasi. Dengan semakin maraknya pelanggaran atau penyalahgunaan hak atas merek yang membahayakan kesehatan, keselamatan jiwa manusia dan lingkungan hidup agar pelanggar jera melakukan pelanggaran dan pemalsuan, maka sanksi pidana denda dan hukuman terhadap pelanggaran merek seyogyanya memang harus diperberat.

\section{Kesiapan Undang-Undang No. 20 Tahun 2016 tentang Merek dan Indikasi Geografis Dalam Menghadapi Masyarakat Ekonomi ASEAN}

Integrasi ekonomi merupakan langkah penting bagi pencapaian Masyarakat Ekonomi ASEAN (MEA) yang berdaya saing dan juga berperan aktif dalam arus ekonomi globa. Keberadaan Masyarakat Ekonomi ASEAN yang akan dilaksanakan pada akhir tahun 2015 merupakan hasil kesepakatan 
para kepala Negara di ASEAN yang tertuang dalam ASEAN Community Blueprint, adapun kesepakatan tersebut adalah sebagai berikut: ${ }^{18}$

a. ASEAN sebagai pasar tunggal ASEAN dan basis produksi Internasional dengan elemen aliran bebas barang jasa, investasi, tenaga kerja terdidik dan aliran modal yang bebas;

b. ASEAN sebagai kawasan dengan daya saing ekonomi yang tinggi, dengan elemen peraturan kompetisi, perlindungan konsumen, hak atas kekayaan Intelektual, pengembangan infrastruktur, perpajakan, dan $e$ commerce.

c. ASEAN sebagai kawasan pengembangan ekonomi yang merata dengan elemen pengembangan usaha kecil dan menengah.

d. ASEAN sebagai kawasan yang terintegrasi secara penuh dengan perekonomian global dengan pendekatan koheren dala hubungan dengan diluar ASEAN. Dan meningkatkan peran di kancah global.

Selanjutnya, dalam cetak biru MEA 2015, kerjasama regional di bidang HKI dipandu oleh ASEAN IPR action plan 2004-2010 dan work plan for ASEAN cooperation on copyrights dengan tujuan untuk mengembangkan budaya belajar dan inovasi, yang didukung oleh profil HKI yang lebih ramah terhadap dunia usaha, investor, penemu dan pencipta di ASEAN. Selain itu rencana aksi tersebut dimaksudkan untuk meningkatkan jejaring dan koordinasi kepedulian masyarakat, peningkatan kapasitas, serta konstribusi industri HKI terhadap peningkatan daya saing dan pembangunan, yang mana tindakannya antara lain: ${ }^{19}$

a. Melaksanakan secara penuh ASEAN IPR action plan 2004-2010 dan work plan for ASEAN Cooperation on Copyrights;

b. Membentuk sistem arsip ASEAN yang dirancang untuk memfasilitasi pembangunan arsip-arsip serta meningkatkan koordinasi antara lembagalembaga HKI di negara-negara ASEAN sebagai kantor penerima, bedasarkan pada bahasa yang dipersyaratan.

c. Melakukan aksesi terhadap protokol Madrid, apabila dimungkinkan.

d. Melanjutkan konsultasi dan pertukaran informasi di antara lembagalembaga penyelenggara nasional di bidang perlindungan HKI.

e. Meningkatkan kerjasama kawasan di bidang pengetahuan tradisional, sumber genetika dan ekspresi budaya tradisional.

${ }^{18}$ Zakariya, Hafid dan Hidayah, Nurul. (2016). "Keberpihakan Kebijakan Pemerintah Kota Surakarta Dan Kabupaten Sukoharjo Dalam Mendukung Daya Saing Umkm Melalu Pendaftaran Merek Kolektif Dalam Menghadapi MEA 2015", Jurnal Universitas Islam Batik Nusantara, disampaikan dalam Seminar Nasional Kearifan Lokal Nilai Adiluhung Batik Indonesia Untuk Daya Saing Internasional, DIES NATALIS XXXIII.

${ }^{19}$ Direktorat Jenderal Kerjasama ASEAN Departemen Luar Negeri RI. (2009). Cetak Biru Komunitas Ekonomi ASEAN (ASEAN Economic Community Blueprint), http://aeccenter.kemendag.go.id/media/176978/cetak-biru-komunitas-ekonomi-ASEAN.pdf, (diunduh 1 November 2016). 
Selanjutnya, dalam ASEAN Intellectual Property Rights Action Plan 2011-2015, terdapat 5 strategi, ${ }^{20}$ yang terkait juga dengan dengan ASEAN Framework Agreement On Intellectual Property Cooperation yang telah diratifikasi dengan Keputusan Presiden Republik Indonesia Nomor 89 Tahun 1995 Tentang Pengesahan ASEAN Framework Agreement On Intellectual Property Cooperation, yaitu: ${ }^{21}$

a. Strategi pertama yaitu " a balanced IP system that takes into account the varying levels of development of Member States and differences in institutional capacity of national IP Offices to enable them to deliver timely, quality, and accessible IP services to promote the region as being conducive to the needs of users and generators of IP" Akan tetapi, mendirikan sistem merek dagang ASEAN, Trademark Office ASEAN, dan perlindungan regional dan internasional merek pelaksanaannya sulit untuk dapat diwujudkan. ASEAN telah berusaha untuk merumuskan mekanisme perlindungan HKI regional. Tetapi mengingat keragaman masing-masing hukum nasional negara ASEAN berbeda, sehingga sulit diharmonisasikan karena setiap negara mempunyai kepentingan perdagangan sendiri untuk negaranya.

b. Strategi kedua yaitu: "developed national or regional legal and policy infrastructures that address evolving demands of the IP landscape and AMSs participate in global IP systems at the appropriate time", Pembentukan konsultan kekayaan intelektual ASEAN untuk menciptakan standar dan praktek konsisten standar internasional ASEAN. Pelaksanaannya terbentuknya ASEAN Intellectual Property Association (IPA ASEAN) pada tanggal 1 Desember 1996 resmi didirikan dan diberi status Official NGO oleh Sekretariat ASEAN pada tahun 1998.

c. Strategi ketiga yaitu: "the interests of the region are advanced through systematic promotion for IP creation, awareness, and utilization to ensure that IP becomes a tool for innovation and development; support for the transfer of technology to promote access to knowledge; and with considerations for the preservation and protection of indigenous products and services and the works of their creative peoples in the region". Memperkuat administrasi kekayaan intelektual ASEAN. Tujuan ini pada intinya akan fokus pada peningkatan efisiensi administrasi, dimana

${ }^{20}$ ASEAN Intellectual Property Portal. (2015). ASEAN Intellectual Property Rights Action Plan 2011-2015, https://www.ASEANip.org/About-Us/ASEAN-IPR-Action-Plan-20112015, (diunduh 3 Desember 2016).

21 Arini, Hermastuti. et.al. (2016). "Implementasi ASEAN Framework Agreement On Intellectual Property Cooperation Dalam Memberikan Perlindungan Merek Bagi Usaha Mikro Kecil Dan Menengah Menghadapi ASEAN Economic Community", Dipenegoro Law Journal, http://ejournal-s1.undip.ac.id/index.php/dlr/article/download/11951/11605, diunduh 3 Desember 2016. 
peningkatan administrasi harus ditunjang dengan dalam hal kemajuan sistem administrasi kantor kekayaan intelektual di setiap anggota negara ASEAN. Masing-masing anggota merencanakan suatu konsep untuk dapat mengurangi biaya pendaftaran dan periode waktu proses mendapatkan sertifikat merek menjadi 6 bulan, karena hal tersebut sangat penting diperhatikan

d. Strategi keempat yaitu: "Active regional participation in the international IP community and with closer relationships with dialogue partners and institutions to develop the capacity of Member States and to address the needs of stakeholders in the region" Pelaksanaannya berupa ASEAN Case Law Database yang ada dalam ASEAN IP Portal. ASEAN Case Law Database merupakan kumpulan data kasus yang terjadi mengenai sengketa IP yang terjadi di negara ASEAN. Tujuannya untuk memberikan informasi agar database ini dapat membantu meningkatkan transparansi dan aksesibilitas terkait di wilayah ASEAN.

e. Strategi kelima yaitu: "intensified cooperation among AMSs and increased level of collaboration among them to enhance human and institutional capacity of IP Offices in the region". Pelaksanaannya adanya ASEAN Trademark View (ASEAN TMview), dimana adalah sebuah platform informasi merek secara online umum dari negara anggota ASEAN yang bertujuan untuk membuat database merek ASEAN yang telah terdaftar agar mudah diakses oleh semua pemangku kepentingan.

Terlepas dari kebijakan ASEAN tersebut, tantangan terbesar dalam perlindungan merek dan indikasi geografis dalam penulisan ini adalah daya saing. Analisis ketentuan-ketentuan baru terhadap Undang-Undang No. 20 Tahun 2016 tentang Merek dan Indikasi Geografis yang berdampak signifikan terhadap daya saing dalam menghadapi Masyarakat Ekonomi ASEAN yang juga dikaitkan dengan Naskah Akademik RUU Merek 2015, yaitu:

\section{a. Perluasan Definisi Merek}

Pada saat berlakukan Undang-Undang Nomor 15 Tahun 2001 tentang Merek, terdapat perkembangan-perkembangan baru yang membutuhkan perubahan atau penyesuaian dalam Undang-Undang Nomor 15 tahun 2001. Perkembangan-perkembangan baru tersebut adalah pertama terdapat jenisjenis merek baru yang berbeda dengan merek dagang konvensional atau dikenal sebagai merek non tradisional. Yaitu merek-merek yang tercakup merek tiga dimensi, merek suara, merek aroma, merek hologram dan sebagainya. Dengan terdapatnya merek jenis baru ini definisi merek tercantum dalam Pasal 1 angka 1 Undang-Undang Nomor 15 Tahun 2001, tidak lagi memadai sehingga perlu adanya perluasan definisi merek diikuti 
perkembangan yang ada. Bahwa dalam rangka menyambut Masyarakat Ekonomi ASEAN yang akan diberlakukan akhir 2015 perekonomian Indonesia saat ini didorong untuk menumbuhkan wirausaha mandiri khususnya usaha mikro, kecil dan menengah.

Sehubungan dengan Usaha Kecil dan Menengah yang membutuhkan pendaftaran merek mudah singkat, murah serta menjamin perlindungan hukum. Munculnya perkembangan-perkembangan baru tersebut mengisyaratkan penguatan regulasi dibidang merek, bahwa mengingat peran sentral merek dalam melindungi kekayaan intelektual dari produk barang dan jasa Indonesia diperlukan peraturan terkait merek yang senantiasa mampu memenuhi perkembangan yang ada untuk melindungi kekhasan produk Indonesia. Guna memperkuat peranan merek dalam melindungi kekayaan intelektual anak bangsa pada akhirnya melindungi karakter khas yang menjadi keunggulan produk barang dan jasa dari Indonesia. ${ }^{22}$ Akan tetapi, merek aroma tidak masuk dalam merek yang dilindungi dalam Undang-Undang No. 20 Tahun 2016 tentang Merek dan Indikasi Geografis. Walaupun merek aroma mempunyai daya pembeda yang kuat seperti aroma kopi merek-merek tertentu, dalam prakteknya memerlukan teknologi tinggi sehingga tidak efektif dalam memberikan perlindungan merek. ${ }^{23}$

\section{b. Permohonan Pendaftaran Merek Internasional}

Konsep dasar Madrid Protocol adalah satu aplikasi merek untuk mendapatkan perlindungan hukum di banyak Negara. Dimana apabila calon pendaftar merek ingin mendaftarkan mereknya di banyak negara maka cukup hanya mengajukan permohonan ke Direktorat Merek Ditjen Hak Kekayaan Intelektual Departemen Hukum dan HAM tertentu saja tidak perlu datang ke masing masing negara yang dituju. Dengan demikian, apabila Indonesia tidak meratifikasi Madrid Protocol maka pemilik merek dari dalam negeri mau tidak mau harus mendaftarkan mereknya di setiap negara. Undang-Undang No. 20 Tahun 2016 tentang Merek dan Indikasi Geografis kini mengadopsi perjanjian Madrid Protocol. Hal ini dapat lebih melindungi kepentingan para pelaku usaha nasional mengingat hanya dengan pendaftaran merek maka merek tersebut akan mendapatkan perlindungan hukum (sistem konstitutif). Pada dasarnya, hampir semua negara

22 Panitia Khusus RUU Tentang Merek. (2016). Laporan Singkat Panitia Khsusus (Pansus) RUU Tentang Merek, Rapat ke-4, http://www.dpr.go.id, (diunduh tanggal 20 Juni 2016).

${ }^{23}$ Pendapat Mahkamah Agung, Panitia Khusus RUU Tentang Merek, Laporan Singkat Panitia Khsusus (Pansus) RUU Tentang Merek, Rapat ke-16. 
menerapkan sistem perlindungan merek yang didasari dengan pendaftaran karena tanpa adanya pendaftaran maka tidak ada perlindungan hukum. ${ }^{24}$

Seperti yang sudah dijelaskan dalam tinjuan pustaka penulisan ini, dimana sistem konstitutif diberlakukan untuk mengantisipasi sistem sebelumnya dalam hal ini adalah sistem deklaratif yang timbul dari peraturan terdahulu yakni Undang Undang No 21 Tahun 1961 tentang Merek Perusahaan dan Merek Perniagaan. Sistem deklaratif adalah suatu sistem di mana hak atas suatu merek timbul karena pemakaian pertama oleh pihak pemilik merek walaupun tidak didaftarkan oleh pemilik merek. Sistem deklaratif mempunyai kelemahan karena tidak diketahui kapan suatu merek akan dipakai oleh seseorang apabila terjadi sengketa antara dua pihak di mana satu pihak mengklaim sebaai pemakai pertama dari merek tersebut sementara pihak lain juga mengklaim hal yang sama, maka untuk membuktikan siapa yang merupakan pemakai pertama dari merek tersebut merupakan hal yang tidak mudah atau sulit. Sebenarnya di dalam sistem deklaratif seperti yang dianut oleh Undang Undang No 21 Tahun 1961 pendaftaran merek tersebut bukan untuk mendapatkan hak atas merek Lebih lanjut sistem ini lebih menitikberatkan terbitnya hak atas merek kepada siapa pemakai pertama merek. Sebelumnya, sebuah pendaftaran hanya semata mata dilakukan untuk kepentingan pembuktian jika di kemudian hari terjadi sengketa merek. Oleh karena itu, karena tidak sesuai lagi maka sistem deklaratif tersebut diubah menjadi sistem konstitutif yaitu suatu sistem di mana hak atas suatu merek tercipta karena adanya pendaftaran dari yang bersangkutan. ${ }^{25}$

Sejauh ini masih terdapat sikap pro dan kontra, keuntungan serta kerugian bagi Indonesia apabila ikut meratifikasi Madrid Protocol hal ini sangat penting untuk dijadikan perbandingan Adapun keuntungan yang akan diperoleh oleh Indonesia adalah sebagai berikut: ${ }^{26}$

1) Dilihat dari segi kepentingan pengusaha lokal

Jika dilihat dari segi kepentingan pengusaha lokal maka pengadobsian Madrid Protocol jelas akan memberikan kemudahan bagi mereka untuk mendaftarkan merek secara internasional di beberapa negara anggota Madrid Protocol yakni cukup dengan satu permohonan yang dapat dilakukan melalui Ditjen Hak Kekayaan Intelektual Tidak dapat dipungkiri bahwa menembus pangsa pasar internasional merupakan impian setiap pelaku usaha yang ingin memasarkan produk mereka. Oleh karena itu mekanisme seperti

${ }^{24}$ Kurnianingrum, Trias Palupi. (2016). Pentingnya Ratifikasi Madrid Protocol Dalam Menghadapi Perdagangan Bebas Di Era Globalisasi, http://ejournal.lipi.go.id, (diakses 10 November), p. 21-22.

${ }^{25}$ Ibid.

${ }^{26}$ Ibid., p. 22-23. 
ini hendaknya dianggap sebagai suatu kesempatan mengingat aspek mudah dan murahnya sehingga pemohon tidak perlu harus datang ke setiap negara di mana pendaftaran merek akan diajukan. Kecuali itu keuntungan lain yang akan di peroleh ialah adanya jaminan dan kepastian hukum internasional terutama di bidang HKI mengingat ratifikasi merupakan suatu perbuatan hukum yang menyatakan keterikatan negara dengan perjanjian internasional melalui produk legislasi nasional Madrid Protocol juga memberikan pilihan penggunaan bahasa dalam melakukan per mohonan pendaftaran merek internasional baik Inggris, Perancis maupun Spanyol. Jika pemohon memilih untuk menggunakan bahasa Inggris maka segala komunikasi dan surat menyurat antara Ditjen HKI dengan WIPO akan dilakukan dengan bahasa Inggris. Hal ini berbanding terbalik dalam Madrid Aggrement yang harus menggunakan bahasa Perancis jadi dapat dikatakan bahwa pemohon tidak perlu untuk menggunakan bahasa resmi negara yang dituju tetapi cukup menggunakan bahasa yang telah dipilih. Oleh karena itu pengadobsian Madrid Protocol dirasakan jelas menguntungkan pengusaha lokal mengingat kendala yang selama ini terjadi dalam menembus pangsa pasar internasional adalah masalah bahasa sehingga secara tidak langsung hal ini akan memudahkan mereka nantinya.

\section{2) Dilihat dari segi kepentingan negara}

Jika dilihat dari segi kepentingan negara jelas sangat menguntungkan bila Pernerintah Indonesia meratifikasi Madrid Protocol sebab secara tidak langsung akan memberi kan masukan devisa kas melalui penerimaan negara bukan pajak mengingat nantinya sinkronisasi hukum nasional dalam bidang merek dengan ketentuan internasional seperti Madrid Protocol akan dapat menjadi salah satu daya penarik dalam bidang ekonomi untuk menarik investasi asing ke Indonesia. Selain itu di dalam Madrid Protocol setiap negara anggota dapat menentukan besarnya biaya permohonan individual fee dengan catatan bahwa besarnya individual fee tidak boleh melebihi besarnya biaya permohonan pendaftaran merek yang berlaku di negaranya. Namun apabila negara anggota tidak menentukan besarnya individual fee maka bagi negara tersebut akan diberlakukan ketentuan complimentary fee yang telah ditentukan besarnya oleh WIPO Hal ini dimaksudkan agar tidak merugikan bagi negara negara yang biaya permohonan pendaftaran mereknya lebih besar jika dibandingkan dengan besarnya complimentary fee.

Sedangkan kerugian yang akan diperoleh oleh Indonesia yaitu pada dasarnya kerugian yang terjadi apabila Indonesia meratifikasi Madrid Protocol ini lebih tertuju pada konsultan HKI mengingat secara tidak langsung semua pendaftaran HKI yang notabene dapat dilakukan melalui konsultan HKI akan menjadi dikesampingkan. Melalui Madrid Protocol semua pendaftaran akan dilakukan langsung ke kantor merek melalui 113 
Konsultan HKI dirasakan akan kehilangan pendapatan melalui pendaftaran secara signifikan meng ingat permohonan merek dari luar negeri dapat memanfaatkan Madrid Protocol ini melalui negaranya tanpa harus menggunakan konsultan HKI di Indonesia yang selama ini berlangsung. Pemilik merek asing yang bertempat tinggal atau berkedudukan tetap di luar negeri dalam mengajukan permintaan pendaftaran merek diwajibkan melalui kuasanya di Indonesia dan diwajibkan pula berdomisili di tempat mereknya didaftarkan dengan cara memberikan kuasa kepada konsultan merek di negara tempat merek asing itu akan didaftarkan dalam hal ini konsultan HKI di Indonesia. Namun jika dicermati lebih jauh sesungguhnya hal ini tidak berdampak besar bagi para konsultan HKI mengingat masih terdapat celah yakni bila permohonan pendaftaran merek internasional akan ditolak maka secara tidak langsung peranan konsultan HKI akan tetap dibutuhkan sehingga mereka tidak serta merta akan kehilangan klien dari luar negeri. Oleh sebab itu dapat dikatakan sebenarnya Madrid Protocol memberikan banyak manfaat khususnya bagi pengusaha Indonesia dalam menghadapi free trade area di era globalisasi saat ini sehingga jika Pemerintah Indonesia berencana untuk meratifikasinya maka pemerintah perlu mendapatkan dukungan para pihak terkait.

\section{3) Penyederhanaan Jangka Waktu Proses Pendaftaran}

Perbandingan proses pendaftaran merek Undang-Undang No. 15 Tahun 2001 dan Undang-Undang No. 20 Tahun 2016 tentang Merek dan Indikasi Geografis, yaitu: ${ }^{27}$

\begin{tabular}{|c|c|}
\hline $\begin{array}{l}\text { Undang-Undang No. } 15 \text { Tahun } \\
\qquad 2001\end{array}$ & $\begin{array}{c}\text { Undang-Undang Undang- } \\
\text { Undang No. } 20 \text { Tahun } 2016 \\
\text { tentang Merek dan Indikasi } \\
\text { Geografis } \\
\end{array}$ \\
\hline Pemohon & Pemeriksaan \\
\hline Formalitas & Formalitas (maksimal 15 hari) $\rightarrow$ \\
\hline$\rightarrow \quad$ Pemeriksaan Substantif & Pengumuman $(2$ bulan $) \rightarrow$ \\
\hline (maksimal 9 bulan) $\rightarrow$ & Keberatan/Sanggahan ( 1 bulan) \\
\hline Pengumuman ( 3 bulan) $\rightarrow$ & Pemeriksaan Substantif (maksimal \\
\hline $\begin{array}{l}\text { Sertifikasi } \rightarrow \text { Total proses } 14 \\
\text { bulan } 10 \text { hari }\end{array}$ & $\begin{array}{l}5 \text { bulan }) \rightarrow \text { Sertifikasi ( } 1 \text { bulan }) \rightarrow \\
\text { Total proses } 9 \text { bulan } 15 \text { hari }\end{array}$ \\
\hline
\end{tabular}

Permohonan merek yang cukup efesien adalah atau tidak memerlukan waktu yang lama. Jika permohonan merek menurut Undang-Undang Merek

${ }^{27}$ Panitia Khusus RUU Tentang Merek. (2016). Laporan Singkat Panitia Khsusus (Pansus) RUU Tentang Merek, Rapat ke-18, http://www.dpr.go.id, (diunduh tanggal 20 Juni 2016). 
yang baru nanti akan berkisar 9 bulan 15 hari, tentu hal itu menjadi hal yang sangat berpengaruh karena sangat cepat proses pendaftaran mereknya. Akan tetapi, perlu dikaji lagi apakah dalam pelaksanaan Undang-Undang Merek yang baru akan sesuai antara praktik dan teorinya (tidak saling bertentangan).

\section{4) Pembinaan dan Pengawasan Indikasi Geografis}

Pembinaan dan pengawasan indikasi geografis merupakan materi baru yang diatur dalam Undang-Undang No. 20 Tahun 2016 tentang Merek dan Indikasi Geografis. Pembinaaan Indikasi Geografis dilakukan oleh Pemerintah Pusat dan/atau Pemerintah Daerah sesuai dengan kewenangannya. Sementara untuk pengawasan dilakukan untuk menjamin tetap adanya reputasi, kualitas, dan karakteristik yang menjadi dasar diterbitkannya Indikasi Geografis; dan mencegah penggunaan Indikasi geografis secara tidak sah. Terkait dengan pembinaan, antara lain meliputi:

a) Persiapan untuk pemenuhan persyaratan Permohonan Indikasi Geografis;

b) Permohonan pendaftaran Indikasi Geografis;

c) Pemanfaatan dan komersialisasi Indikasi Geografis;

d) Melakukan sosialisasi dan pemahaman atas pelindungan Indikasi Geografis;

e) Melakukan pemetaan dan inventarisasi potensi produk Indikasi Geografis;

f) Melakukan pelatihan dan pendampingan

g) Pemantauan, evaluasi, dan pembinaan;

h) Memberikan pelindungan hukum; dan

i) Memfasilitasi pengembangan, pengolahan, dan pemasaran produk Indikasi Geografis.

Dengan adanya ketentuan pembinaan dan pengawasan indikasi geografis maka akan dapat meningkatkan daya saing dalam menghadapi MEA. Terlebih terhadap pembinaan perlindungan indikasi geografis ini sangat penting untuk meningkatkan daya saing pelaku usaha, karena Pertama, indikasi geografis penting karena mengidentifikasi sumber atau asal produk. Kedua, indikasi geografis mengindikasikan kualitas produk dengan menginformasikan konsumen bahwa suatu barang berasal dari daerah atau wilayah yang memberikan kualitas, reputasi, atau karakteristik lainnya yang esensial dapat dikaitkan dengan asal geografisnya. Ketiga, indikasi geografis dapat mempresentasikan kepentingan bisnis (business interest) karena menjamin keaslian suatu barang yang berkarakteristik dari daerah tertentu. ${ }^{28}$

${ }^{28}$ Ibid. 
Selanjutnya, berdasarkan Pasal 60 Undang-Undang No. 20 Tahun 2016 tentang Merek dan Indikasi Geografis menyatakan "Ketentuan lebih lanjut mengenai syarat dan tata cara pendaftaran Indikasi Geografis serta pengangkatan anggota, susunan organisasi, tugas, dan fungsi Tim Ahli Indikasi Geografis sebagaimana dimaksud dalam Pasal 56 sampai dengan Pasal 59 diatur dengan Peraturan Menteri”. Perlu digarisbawahi bahwa selama ini produk nasional sulit didaftarkan untuk memperoleh perlindungan indikasi geografis berdasarkan Peraturan Pemerintah Republik Indonesia Nomor 51 Tahun 2007 Tentang Indikasi Geografis. Alih-alih melindungi produk nasional melalui pendaftaran indikasi geografis, produk asing justru memperoleh perlindungan karena didaftarkan di Indonesia. Padahal ketentuan indikasi geografis dalam perjanjian TRIPs bersifat open source, sehingga terbuka peluang bagi pemerintah untuk mengatur sesuai dengan kepentingan nasional. ${ }^{29}$ Dengan demikian ini merupakan saat yang tepat untuk dimanfaatkan oleh pemerintah Indonesia dengan peraturan menteri terkait membuat peraturan yang bermanfaat sebesar-besarnya untuk kepentingan nasional.

\section{5) Penggunaan Media Elektronik Atau Non- Elektronik}

Dalam rangka menjawab tantangan global dan seiring dengan perkembangan perekonomian, sektor perdagangan, teknologi, dan hubungan internasional, Undang-Undang No. 20 Tahun 2016 tentang Merek dan Indikasi Geografis turut mengatur mengenai permohonan pendaftaran merek dengan menggunakan sarana/media elektronik. Pemohon baik secara langsung maupun melalui kuasanya dapat mengajukan permohonan pendaftaran merek secara langsung melalui sistem aplikasi dunia maya atau online yang disediakan oleh kementerian terkait. Hal ini tentunya mempermudah pendaftaran merek baik pengajuan yang pemohonnya adalah orang/badan hukum nasional maupun pengajuan merek dagang milik orang atau badan hukum internasional. Selain itu bagi pihak yang mengajukan permohonan maupun yang memiliki kepentingan atas merek yang didaftar dapat memantau secara berkala mengenai permohonan pengajuan pendaftarannya dalam berita resmi merek yang secara kontinu diumumkan melalui sarana elektronik tersebut. ${ }^{30}$ Selanjutnya, diatur juga ketentuan sistem jaringan dokumentasi dan informasi dalam Pasal 80 dan Pasal 81, sistem jaringan dokumentasi dan informasi merek dan indikasi geografis sebagaimana diatur dalam undang-undang ini dilaksanakan oleh Menteri. Sistem jaringan dokumentasi dan informasi merek dan indikasi geografis

29 Sasongko, Wahyu. (2010). "Indikasi Geografis Studi Tentang Kesiapan Indonesia Memberikan Perlindungan Hukum Terhadap Produk Nasional”, Disertasi Program Doktor Pascasarjana Fakultas Hukum Universitas Indonesia, p. 103.

${ }^{30}$ Ibid. 
diselenggarakan melalui sarana elektronik dan/atau non-elektronik yang dapat diakses secara nasional dan internasional.

\section{Penutup \\ 1. Simpulan}

Pembaruan substansial perlindungan hukum merek dan indikasi geografis menurut Undang-Undang No. 20 Tahun 2016 tentang Merek dan Indikasi Geografis, antara lain: perluasan definisi merek; permohonan pendaftaran merek internasional; ketentuan mengenai merek yang tidak dapat didaftar dan ditolak; penyederhanaan jangka waktu proses pendaftaran; ketentuan mengenai merek generik; penarikan sertifikat merek yang tidak diambil pemiliknya; perpanjangan merek terdaftar berupa logo; tenaga ahli pemeriksa merek di luar pemeriksa; perbaikan atau koreksi yang dilakukan pada permohonan merek; perubahan nama dan/atau alamat pemilik merek dapat dilakukan pada saat proses permohonan pendaftaran merek; ketentuan biaya dan denda perpanjangan jangka waktu perlindungan merek; perlindungan indikasi geografis; ketentuan mengenai indikasi asal; penggunaan media elektronik atau non- elektronik; pembinaan dan pengawasan indikasi geografis; penghapusan dan pembatalan pendaftaran merek; ketentuan penyelesaian sengketa; dan ketentuan pidana.

Cetak biru pembentukan Masyarakat Ekonomi ASEAN dibuat berdasarkan empat pilar yang saling berhubungan dan menguatkan, yaitu: (a) pasar tunggal dan basis produksi pasar tunggal, (b) kawasan ekonomi yang berdaya saing, (c) ekonomi yang merata, dan (e) integrasi dengan ekonomi global. Kajian Hak kekayaan intelektual menekan pada aspek pilar kedua yaitu kawasan ekonomi yang berdaya saing, selanjutnya dalam cetak biru MEA 2015, kebijakan kerjasama regional di bidang HKI dipandu oleh ASEAN Intellectual Property Rights Action Plan 2011-2015. Kesiapan perlindungan Undang-Undang No. 20 Tahun 2016 tentang Merek dan Indikasi Geografis dalam menghadapi era Masyarakat Ekonomi ASEAN yang menekankan pada kawasan ekonomi yang berdaya saing, antara lain

a) Perluasan definisi merek

b) Pendaftaran Merek internasional berdasarkan Protokol Madrid

c) Penyederhanaan Jangka waktu proses pendaftaran Merek

f) Adanya pembinaan dan pengawasan indikasi geografis

g) Penggunaan media elektronik atau non- elektronik, serta sistem jaringan dokumentasi dan informasi merek dan indikasi geografis diselenggarakan melalui sarana elektronik dan/atau non-elektronik yang dapat diakses secara nasional dan internasional. 


\section{Saran}

a. Dalam menghadapi era Masyarakat Ekonomi ASEAN, maka kedepannya diperlukan sosialisasi kepada masyarakat terhadap Undang-Undang No. 20 Tahun 2016 tentang Merek dan Indikasi Geografis, untuk meningkatkan pemahaman mengenai prosedur pendaftaran merek dan penerapan pendaftaran secara elektronik; prosedur pendaftaran indikasi geografis, standarisasi merek terkenal untuk menolak permohonan pendaftaran merek dan prosedur permohonan pendaftaran merek internasional.

b. Permohonan pendaftaran merek dan permohonan jangka waktu perlindungan merek dapat diajukan secara elektronik dan non elektronik. Ketentuan ini dimaksudkan untuk mewujudkan sistem elektronik filling dalam seluruh proses permohonan pendaftaran Merek khususnya dan pendaftaran kekayaan intelektual pada umumnya. Akan tetapi, diperlukan penguatan infrastuktur non elektronik seluruh Indonesia agar menjamin pemerataan dan kepastian hukum penerapan Undang-Undang No. 20 Tahun 2016 tentang Merek dan Indikasi Geografis.

c. Pembaruan substansial dalam menghadapi Masyarakat Ekonomi ASEAN, ketentuannya memerlukan Peraturan Pemerintah dan Peraturan Menteri lebih lanjut, dimana ini saat yang tepat untuk dimanfaatkan oleh pemerintah Indonesia sebaik-baiknya untuk membuat Peraturan Pemerintah dan Peraturan Menteri yang bermanfaat sebesar-besarnya untuk kepentingan nasional.

\section{Daftar Pustaka}

\section{A. Buku, Karya Ilmiah}

Bappeda Kabupaten Malang. (2015). Kabupaten Malang menuju MEA 2015. Jawa Timur: Bappeda Kabupaten Malang.

Erinaldi. (2012). "Pemberian Hak Merek Generik dan Merek Deskriptif Dalam Pendaftaran Merek", Tesis Fakultas Hukum Program Studi Pasca Sarjana Universitas Indonesia.

Sasongko, Wahyu. (2010). "Indikasi Geografis Studi Tentang Kesiapan Indonesia Memberikan Perlindungan Hukum Terhadap Produk

Nasional", Disertasi Program Doktor Pascasarjana Fakultas Hukum Universitas Indonesia.

Zakariya, Hafid dan Hidayah, Nurul. (2016). "Keberpihakan Kebijakan

Pemerintah Kota Surakarta Dan Kabupaten Sukoharjo Dalam Mendukung Daya Saing UMKM Melalui Pendaftaran Merek Kolektif Dalam Menghadapi Mea 2015”, Jurnal Universitas Islam Batik Nusantara, disampaikan dalam Seminar Nasional Kearifan Lokal 
Nilai Adiluhung Batik Indonesia Untuk Daya Saing Internasional, DIES NATALIS XXXIII.

\section{B. Peraturan Perundang-Undangan}

Undang-Undang No. 20 Tahun 2016 tentang Merek dan Indikasi Geografis.

Peraturan Pemerintah Republik Indonesia Nomor 51 Tahun 2007 Tentang Indikasi Geografis.

Peraturan Pemerintah Republik Indonesia Nomor 23 Tahun 1993 tentang Tata Cara Permintaan Pendaftaran Merek.

Peraturan Pemerintah Republik Indonesia Nomor 24 Tahun 1993 tentang Kelas Barang atau Jasa Bagi Pendaftaran Merek.

Keputusan Presiden Republik Indonesia Nomor 89 Tahun 1995 Tentang Pengesahan ASEAN Framework Agreement On Intellectual Property Cooperation.

\section{Website}

Arini, Hermastuti. et.al. (2016). Implementasi ASEAN Framework Agreement On Intellectual Property Cooperation Dalam Memberikan Perlindungan Merek Bagi Usaha Mikro Kecil Dan Menengah Menghadapi ASEAN Economic Community, Dipenegoro Law Journal, http://ejournal-s1.undip.ac.id/index.php/dlr/article/download/11951/11 605, (diunduh 3 Desember 2016).

ASEAN Intellectual Property Portal. (2015). ASEAN Intellectual Property Rights Action Plan 2011-2015, https://www.ASEANip.org/AboutUs/ASEAN-IPR-Action-Plan-2011-2015, (diunduh 3 Desember 2016).

Kementerian Perdagangan. (2015). Laporan Analisis Daya Saing Indonesia Dan ASEAN Lainnya Di Pasar Produk Utama Indonesia Pusat, Pusat Kebijakan Perdagangan Luar Negeri Badan Pengkajian Dan Pengembangan Kebijakan Perdagangan Kementerian Perdagangan, Pustaka Daglu, http://www.kemendag.go.id/files/pdf/2016/06/15/anali sis-daya-saing1465976277.pdf, (diunduh 1 Desember 2016).

Panitia Khusus RUU Tentang Merek. (2015). Laporan Singkat Panitia Khsusus (Pansus) RUU Tentang Merek. Rapat ke-4, http://www.dpr.go.id/doksileg/proses3/RJ3-20151210-0657421753.pdf, (diakses 27 November 2016). (2015). Laporan Singkat Panitia Khsusus (Pansus) RUU Tentang Merek. Rapat ke-5, http://www.dpr.go.id/doksileg/ proses3/RJ3-20151202-102242-2879.pdf, (diakses 27 November 2016).

RUU Tentang Merek. Rapat ke-18, http://www.dpr.go.id/doksileg/ 
proses3/RJ3-20161115-114339-4610.pdf, (diakses 27 November 2016).

. (2015). Laporan Singkat Panitia Khsusus (Pansus) RUU Tentang Merek. Rapat ke-16, http://www.dpr.go.id/doksileg/ proses3/RJ3-20161115-114225-5100.pdf, (diakses 27 November 2016).

(2015). Laporan Singkat Panitia Khsusus (Pansus) RUU Tentang Merek. Rapat ke-51, http://www.dpr.go.id/doksileg /proses3/RJ3-20161115-114653-9152.pdf, (diakses 27 November 2016).

Rahmawati, Debrina. et.al, Perlindungan Hukum Atas Indikasi Geografis (Studi Perbandingan Hukum Indonesia Dengan Australia), http://hukum.studentjournal.ub.ac.id/index.php/hukum/article/downlo ad/1535/1283, (diakses 12 November 2016). 